\title{
EVIDENCE-BASED PRACTICE (EBP): BELIEFS, KNOWLEDGE AND BEHAVIOR OF PHYSIOTHERAPISTS. A SURVEY RESEARCH.
}

\author{
Collebrusco Luca ${ }^{1}$, Gambacorta Andrea ${ }^{1}$, Visciano Gennaro ${ }^{1}$ \\ ${ }^{1}$ Rehabilitation Unit, National Health Service Umbria Region, Perugia, Italy
}

KEYWORDS: Evidence-based practice, Physical therapy, Professional role behaviors

\section{ABSTRACT}

An analytical observational study was conduct using a web-based questionnaire. Evidence-based practice is one of the most relevant concern of all health professions. This research has been done taking account of demographic information, attitudes and skills in reference to Evidence Based Practice (EBP) for application in the daily clinical practice. To describe beliefs and behaviors of physiotherapists from two Italian regions about EBP and its implementation in clinical practice, their knowledge in this field and the perception of its benefits and barrier in application in clinical practice. The participants completed a designed questionnaire, whose purpose was to determine beliefs, attitudes, knowledge, and behaviors regarding EBP, as well as demographic information about themselves and their practice settings. This survey was activated through the TSRM-PSTRP registers of Marche and Umbria regions that sent the questionnaire to all the registered physiotherapists. There was a response rate of $7.64 \%$ for Marche region, equal to a sample of 132 physiotherapists, and a response rate of $12.99 \%$ for Umbria region, equal to a sample of 110 physiotherapists, for a total sample of 242 physiotherapists. The questionnaire was filled out through an online Google platform called "Forms". The responses were summarized for each item and the logistic regression analyses and the chi-square test were used to examine relationships among variables. The respondents agreed that the use of evidence in practice was necessary, that the literature was helpful in their practices and that the quality of patient care was better when evidence were used. For physiotherapists from Umbria, with more than 15 years of qualification, the following answers are statistically significant $(p<0.05)$ : "the application of EBP is necessary in the practice of physical therapy, EBP helps me making decisions about patient care and I actively seek practice guidelines pertaining to areas of my practice and EBP improves the quality of patient care". For physiotherapists from Marche, with more than 15 years of qualification, the following answers are statistically significant $(p<0.05)$ : "EBP helps me making decisions about patient care, I actively seek practice guidelines pertaining to areas of my practice and I am confident in my ability to find relevant research to answer my clinical questions". Training, familiarity with and confidence in search strategies, use of databases, and critical appraisal tended to be associated to younger therapists with fewer years of qualification. Physical therapists stated they have a positive attitude about EBP and they are interested in learning or improving the necessary skills to implement EBP. They noticed that they needed to increase the use of evidence in their daily practice.

\section{INTRODUCTION}

The interest of physiotherapists in the application of Evidence Based Practice (EBP) in professional practice has grown more and more in the last decade, as demonstrated, in part, by a number of systematic reviews ${ }^{1,2,3,4}$ and in several articles in the literature ${ }^{5}$. Sackett et $\mathrm{al}^{6}$ defined evidence-based medicine as "the use of the best current evidence in making decisions about the care of individual patients " 7,8 . Health professionals' knowledge of EBP is an added component in daily functional clinical activities, which, together with patients' preferences, should increasingly be part of the decision-making process. The concept of EBP marks a change in the nonmedical health professions from opinion-based actions to those based on relevant clinical studies. To effectively apply EBP in the everyday professional context, in addition to skills in the different subclasses of functional assessment ${ }^{5}$, Guyatt et $\mathrm{al}^{9}$ argue that one must have the skills to: (1) identify gaps in knowledge; (2) clinically formulate relevant questions; (3) conduct an efficient literature search; (4) apply a rigorous rationale for determining the validity of studies; (5) apply findings from the literature appropriately to the patient's problem; (6) understand how patient values may influence the balance between potential advantages and disadvantages in involving the patient in decisions ${ }^{5}$. The inability to perform any of these functions represents an obstacle to the application of EBP. The aforementioned criteria can also be extended to non-medical health professions such as physiotherapists, also in the light of art. 5 of law no. 24 of 8 March 20171, since to build solid clinicalassistance guidelines and good practices, one of the cornerstones is knowing how to research and interpret EBP literature. Working through EBP can imply difficulties because of the lack of capacity to use technology tools to find the literature and especially because of the lack of educational basis in order to analyse the results in a rational way ${ }^{10}$. It would be better, therefore, to promote and improve access to efficiency tests summaries, rather than to teach all health professionals about research methodology, and at the same time to encourage the development of guidelines and advice based on the EBP ${ }^{11,12}$. To work, taking in account EBP, is useful to integrate 


\begin{tabular}{|c|c|c|c|c|c|}
\hline Feature & $\begin{array}{l}\text { Percentage } \\
\text { (\%) Umbria }\end{array}$ & $\begin{array}{l}\text { Percentage } \\
\text { (\%) Marche }\end{array}$ & $\begin{array}{l}\text { Number } \\
\text { Umbria }\end{array}$ & $\begin{array}{l}\text { Number } \\
\text { Marche }\end{array}$ & $\begin{array}{l}\text { Number } \\
(\%) \text { Total }\end{array}$ \\
\hline \multicolumn{6}{|l|}{ - SEX } \\
\hline Male & $42.7 \%$ & $38.6 \%$ & 47 & 51 & $98 / 40.5 \%$ \\
\hline Female & $57.3 \%$ & $61.4 \%$ & 63 & 81 & $144 / 59.5 \%$ \\
\hline \multicolumn{6}{|l|}{ - AGE } \\
\hline $20-29$ & $16.4 \%$ & $15.9 \%$ & 18 & 21 & $39 / 16.1 \%$ \\
\hline $30-39$ & $26.4 \%$ & $33.3 \%$ & 29 & 44 & $73 / 30.2 \%$ \\
\hline $40-49$ & $20 \%$ & $18.9 \%$ & 22 & 25 & $47 / 19.4 \%$ \\
\hline$>50$ & $37.3 \%$ & $31.8 \%$ & 41 & 42 & $83 / 34.3 \%$ \\
\hline \multicolumn{6}{|l|}{ - QUALIFICATION } \\
\hline Postgraduate course & $21.8 \%$ & $40.2 \%$ & 20 & 44 & $64 / 26.4 \%$ \\
\hline Master's Degree (LM/SNT2) & $20 \%$ & $15.9 \%$ & 22 & 21 & $43 / 17.8 \%$ \\
\hline First level master's degree & $31.8 \%$ & $29.5 \%$ & 22 & 30 & $52 / 21.5 \%$ \\
\hline Second level master's Degree & $1.8 \%$ & $0.8 \%$ & 1 & - & $1 / 0.4 \%$ \\
\hline $\mathrm{PhD}$ & - & - & - & - & $0 / 0 \%$ \\
\hline Equivalent degree $^{*}$ & $40.9 \%$ & $28 \%$ & 45 & 37 & $82 / 33.9 \%$ \\
\hline \multicolumn{6}{|l|}{ - YEARS OF QUALIFICATION } \\
\hline$<5$ & $12.7 \%$ & $14.4 \%$ & 14 & 19 & $33 / 13.6 \%$ \\
\hline $5-10$ & $16.4 \%$ & $22.7 \%$ & 18 & 30 & $48 / 19.8 \%$ \\
\hline $11-15$ & $17.3 \%$ & $12.1 \%$ & 19 & 16 & $35 / 14.5 \%$ \\
\hline$>15$ & $53.6 \%$ & $50.8 \%$ & 59 & 67 & $126 / 52.1 \%$ \\
\hline \multicolumn{6}{|l|}{ - SPECIALISATION } \\
\hline Neonatal and Pediatric Rehab. & $4.5 \%$ & $2.3 \%$ & 5 & 3 & $8 / 3.3 \%$ \\
\hline Neurological/Neuropsychiatric Rehab. & $36.4 \%$ & $22.7 \%$ & 40 & 30 & $70 / 28.9 \%$ \\
\hline Muscle/Skeletal Rehab & $32.7 \%$ & $50 \%$ & 36 & 66 & $102 / 42.1 \%$ \\
\hline Cardio/Respiratory Rehab. & $2.7 \%$ & $7.6 \%$ & 3 & 10 & $13 / 5.4 \%$ \\
\hline Geriatric Rehab. & $0.9 \%$ & $3.8 \%$ & 1 & 5 & $6 / 2.5 \%$ \\
\hline Sports Rehab. & $0.9 \%$ & $0.8 \%$ & 1 & 1 & $2 / 0.8 \%$ \\
\hline Oncological Rehab. & $1.8 \%$ & 0 & 2 & 0 & $2 / 0.8 \%$ \\
\hline Visceral Rehab. & $0.9 \%$ & $1.5 \%$ & 1 & 2 & $3 / 1.2 \%$ \\
\hline None & $12.7 \%$ & $8.3 \%$ & 14 & 11 & $25 / 10.3 \%$ \\
\hline Others & $6.4 \%$ & $3 \%$ & 7 & 4 & $11 / 4.5 \%$ \\
\hline \multicolumn{6}{|l|}{ - TYPE OF WORK } \\
\hline Employee & $68.2 \%$ & $59.1 \%$ & 75 & 78 & $153 / 63.2 \%$ \\
\hline Freelancer & $31.8 \%$ & $40.9 \%$ & 35 & 54 & $89 / 36.8 \%$ \\
\hline \multicolumn{6}{|l|}{ - PROVINCE OF ORIGIN } \\
\hline Perugia & $86.4 \%$ & - & 95 & - & $95 / 39.3 \%$ \\
\hline \multirow[t]{2}{*}{ Terni } & $13,6 \%$ & - & 15 & - & $15 / 6.2 \%$ \\
\hline & \multicolumn{2}{|c|}{ TOTAL UMBRIA } & 110 & & \\
\hline Ancona-Ascoli Piceno-Fermo-Macerata & - & $99,2 \%$ & - & 131 & $131 / 54 \%$ \\
\hline Pesaro Urbino & - & $0,8 \%$ & - & 1 & $1 / 0.4 \%$ \\
\hline & & \multicolumn{2}{|c|}{ TOTAL MARCHE } & 132 & \\
\hline
\end{tabular}

Tab. 1 - Demographic characteristics of respondents.

Legend: LM/SNT2: Degree Class Rehabilitation Sciences of Health Professions, Rehabilitation, * Law 26 February 1999 , n.42 art.4 paragraph 1.

individual clinical experience with the best articles in the literature through a meticulous systematic review $^{6}$. To date, little research has been done on attitudes towards the use of EBP by physiotherapists for patient management ${ }^{13,14,3,15}$. The aim of our work was to investigate on the attitudes and skills of registered physiotherapists of the National Federation of the Orders of Medical Radiology Technicians and of the Technical, Rehabilitation and Prevention Health Professions (TSRM-PSRTP), of the Marche and Umbria regions. In order to achieve this aim, we made a computerized questionnaire. The cognitive survey could help to highlight shortcomings and criticalities in the use of EBP by physiotherapists. Moreover, it could be useful to evaluate how far the world of education and training is from the world of work. The data collected were analysed to check if there was a significant association among the responses to the questionnaire and the demographic, educational and professional characteristics of physiotherapists 2 .

\section{MATERIAL AND METHODS}

The survey was spread thanks to the Boards of Physiotherapists of the two regions, which sent the questionnaire (Annex 1) to the e-mail addresses of registered physiotherapists. The survey model used as a tool for the collection of data, useful for this survey, is the "Computer Assisted Web Interviewing" (CAWI)3 survey. This tool permits an immediate collection of the data that will be the object of the study analysis. Respondents can answer at the time they consider most appropriate, with the guarantee of maximum confidentiality. The questionnaire administered was developed according to the psychometric technique of attitude measurement elaborated by the psychologist Rensis Likert4 (Likert scale), and consists of three 


\begin{tabular}{|c|c|c|c|c|c|}
\hline Feature & $\begin{array}{l}\text { Percentage } \\
\% \text { Umbra }\end{array}$ & $\begin{array}{l}\text { Percentage } \\
\text { \% Marche }\end{array}$ & $\begin{array}{l}\text { Number } \\
\text { Umbria }\end{array}$ & $\begin{array}{l}\text { Number } \\
\text { Marche }\end{array}$ & $\begin{array}{c}\text { Total } \\
\text { number } / \%\end{array}$ \\
\hline \multicolumn{6}{|c|}{$\begin{array}{l}\text { Application of EBP is necessary in } \\
\text { the practice of physiotherapists }\end{array}$} \\
\hline Strongly disagree & - & - & - & - & - \\
\hline Disagree & & $0.8 \%$ & - & 1 & $1 / 0.4 \%$ \\
\hline Neutral & $11.8 \%$ & $15.9 \%$ & 13 & 21 & $34 / 14 \%$ \\
\hline Agree & $53.6 \%$ & $49.2 \%$ & 59 & 65 & $124 / 51.2 \%$ \\
\hline Strongly agree & $34.5 \%$ & $34.1 \%$ & 38 & 45 & $83 / 34.3 \%$ \\
\hline \multicolumn{6}{|c|}{$\begin{array}{l}\text { Scientific literature and research } \\
\text { results are useful in my daily } \\
\text { practice }\end{array}$} \\
\hline Strongly disagree & - & - & - & - & - \\
\hline Disagree & - & $2.3 \%$ & - & 3 & $3 / 1.2 \%$ \\
\hline Neutral & $13.6 \%$ & $10.6 \%$ & 15 & 14 & $29 / 12 \%$ \\
\hline Agree & $57.3 \%$ & $63.6 \%$ & 63 & 84 & $147 / 60.7 \%$ \\
\hline Strongly agree & $29.1 \%$ & $23.5 \%$ & 32 & 31 & $63 / 26 \%$ \\
\hline \multicolumn{6}{|c|}{$\begin{array}{l}\text { I need to increase the use of the } \\
\text { evidence literature in my daily } \\
\text { clinical practice }\end{array}$} \\
\hline Strongly disagree & $0.9 \%$ & - & 1 & - & $1 / 0.4 \%$ \\
\hline Disagree & - & $3 \%$ & 0 & 4 & $4 / 1.7 \%$ \\
\hline Neutral & $20.9 \%$ & $18.2 \%$ & 23 & 24 & $47 / 19.4 \%$ \\
\hline Agree & $48.2 \%$ & $57.6 \%$ & 53 & 76 & $129 / 53.3 \%$ \\
\hline Strongly agree & $30 \%$ & $21.2 \%$ & 33 & 28 & $61 / 25.2 \%$ \\
\hline \multicolumn{6}{|c|}{$\begin{array}{l}\text { Adaptation of evidence-based } \\
\text { practice is an unreasonable demand } \\
\text { on physiotherapists }\end{array}$} \\
\hline Strongly disagree & $27.3 \%$ & $20.5 \%$ & 30 & 27 & $57 / 23.6 \%$ \\
\hline Disagree & $45.5 \%$ & $47 \%$ & 50 & 62 & $112 / 46.3 \%$ \\
\hline Neutral & $16.4 \%$ & $20.5 \%$ & 18 & 27 & $45 / 18.6 \%$ \\
\hline Agree & $10 \%$ & $11.4 \%$ & 11 & 15 & $26 / 10.7 \%$ \\
\hline Strongly agree & $0.9 \%$ & $0.8 \%$ & 1 & 1 & $2 / 0.8 \%$ \\
\hline \multicolumn{6}{|c|}{$\begin{array}{l}\text { I am interested in learning or } \\
\text { improving the skills needed to } \\
\text { incorporate evidence-based practice }\end{array}$} \\
\hline Strongly disagree & - & - & - & - & - \\
\hline Disagree & $0.9 \%$ & $1.5 \%$ & 1 & 2 & $3 / 1.2 \%$ \\
\hline Neutral & $6.4 \%$ & $11.4 \%$ & 7 & 15 & $22 / 9.1 \%$ \\
\hline Agree & $62.7 \%$ & $55.3 \%$ & 69 & 73 & $142 / 58.7 \%$ \\
\hline Strongly agree & $30 \%$ & $31.8 \%$ & 33 & 42 & $75 / 31 \%$ \\
\hline \multicolumn{6}{|c|}{$\begin{array}{l}\text { Evidence-based practice improves } \\
\text { quality of care }\end{array}$} \\
\hline Strongly disagree & - & $0.8 \%$ & - & 1 & $1 / 0.4 \%$ \\
\hline Disagree & $0.9 \%$ & $7.6 \%$ & 1 & 10 & $11 / 4.5 \%$ \\
\hline Neutral & $18.2 \%$ & $9.1 \%$ & 20 & 12 & $32 / 13.2 \%$ \\
\hline Agree & $50 \%$ & $54.5 \%$ & 55 & 72 & $127 / 52.5 \%$ \\
\hline Strongly agree & $30.9 \%$ & $28 \%$ & 34 & 37 & $71 / 29.3 \%$ \\
\hline \multicolumn{6}{|c|}{$\begin{array}{l}\text { Evidence-based practice does NOT } \\
\text { take into account the limitations of } \\
\text { my rehabilitation setting }\end{array}$} \\
\hline Strongly disagree & $2.7 \%$ & $0.8 \%$ & 3 & 1 & $4 / 1.7 \%$ \\
\hline Disagree & $20.0 \%$ & $22 \%$ & 22 & 29 & $51 / 21.1 \%$ \\
\hline Neutral & $35.5 \%$ & $42.4 \%$ & 39 & 56 & $95 / 39.3 \%$ \\
\hline Agree & $37.3 \%$ & $31.8 \%$ & 41 & 42 & $83 / 34.3 \%$ \\
\hline Strongly agree & $4.5 \%$ & $3 \%$ & 5 & 4 & $9 / 3.7 \%$ \\
\hline \multicolumn{6}{|c|}{$\begin{array}{l}\text { My gains increase if I use EBP in my } \\
\text { daily practice }\end{array}$} \\
\hline Strongly disagree & $11.8 \%$ & $14.4 \%$ & 13 & 19 & $32 / 13.2 \%$ \\
\hline Disagree & $22.7 \%$ & $23.5 \%$ & 25 & 31 & $56 / 23.1 \%$ \\
\hline Neutral & $55.5 \%$ & $53 \%$ & 61 & 70 & $131 / 54.1 \%$ \\
\hline Agree & $8.2 \%$ & $8.3 \%$ & 9 & 11 & $20 / 8.3 \%$ \\
\hline Strongly agree & $1.8 \%$ & $0.8 \%$ & 2 & 1 & $3 / 1.2 \%$ \\
\hline
\end{tabular}




\begin{tabular}{|c|c|c|c|c|c|c|}
\hline \multicolumn{7}{|c|}{$\begin{array}{l}\text { Lack of clear evidence to support } \\
\text { most of the interventions I use with } \\
\text { my patients }\end{array}$} \\
\hline Strongly disagree & $4.5 \%$ & $6.8 \%$ & & 5 & 9 & $14 / 5.8 \%$ \\
\hline Disagree & $34.5 \%$ & $40.9 \%$ & & 38 & 54 & $92 / 38 \%$ \\
\hline Neutral & $32.7 \%$ & $32.6 \%$ & & 36 & 43 & $79 / 32.6 \%$ \\
\hline Agree & $23.6 \%$ & $17.4 \%$ & & 26 & 23 & $49 / 20.2 \%$ \\
\hline Strongly agree & $4.5 \%$ & $2.3 \%$ & & 5 & 3 & $8 / 3.3 \%$ \\
\hline \multicolumn{7}{|c|}{$\begin{array}{l}\text { EBP helps me to make decisions } \\
\text { about the clinical management of } \\
\text { patients }\end{array}$} \\
\hline Strongly disagree & $1.8 \%$ & - & & 2 & - & $2 / 0.8 \%$ \\
\hline Disagree & $4.5 \%$ & $8.3 \%$ & & 5 & 11 & $16 / 16.6 \%$ \\
\hline Neutral & $23.6 \%$ & $20.5 \%$ & & 26 & 27 & $53 / 21.9 \%$ \\
\hline Agree & $55.5 \%$ & $56.8 \%$ & & 61 & 75 & $136 / 56.2 \%$ \\
\hline Strongly agree & $14.5 \%$ & $14.4 \%$ & & 16 & 19 & $35 / 14.5 \%$ \\
\hline \multicolumn{7}{|c|}{$\begin{array}{l}\text { EBP does NOT take patient } \\
\text { preferences into account }\end{array}$} \\
\hline Strongly disagree & $9.1 \%$ & $6.8 \%$ & & 10 & 9 & $19 / 7.9 \%$ \\
\hline Disagree & $24.5 \%$ & $25 \%$ & & 27 & 33 & $60 / 24.8 \%$ \\
\hline Neutral & $38.2 \%$ & $38.6 \%$ & & 42 & 51 & $93 / 38.4 \%$ \\
\hline Agree & $21.8 \%$ & $25.8 \%$ & & 24 & 34 & $58 / 24 \%$ \\
\hline Strongly agree & $6.4 \%$ & $3.8 \%$ & & 7 & 5 & $12 / 5 \%$ \\
\hline \multicolumn{7}{|c|}{$\begin{array}{l}\text { How many articles can you read if } \\
\text { you combine research and clinical } \\
\text { work in one month? }\end{array}$} \\
\hline $0-3$ per month & $60.9 \%$ & $67.4 \%$ & & 67 & 89 & $156 / 64.5 \%$ \\
\hline $3-5$ per month & $19.1 \%$ & $22.7 \%$ & & 21 & 30 & $51 / 21.1 \%$ \\
\hline $6-10$ per month & $14.5 \%$ & $3.8 \%$ & & 16 & 5 & $21 / 8.7 \%$ \\
\hline $11-15$ per month & - & $2.3 \%$ & & - & 3 & $3 / 1.2 \%$ \\
\hline More & $5.5 \%$ & $3.8 \%$ & & 6 & 5 & $11 / 4.5 \%$ \\
\hline \multicolumn{7}{|c|}{$\begin{array}{l}\text { I use research results in the clinical/ } \\
\text { decision-making process }\end{array}$} \\
\hline$<1$ time per month & $41.8 \%$ & $35.6 \%$ & 46 & 47 & \multicolumn{2}{|c|}{$93 / 38.4 \%$} \\
\hline 2 - 5 times per month & $34.5 \%$ & $40.9 \%$ & 38 & 54 & \multicolumn{2}{|c|}{$92 / 38 \%$} \\
\hline 6 - 10 times per month & $16.4 \%$ & $13.6 \%$ & 18 & 18 & \multicolumn{2}{|c|}{$36 / 14.9 \%$} \\
\hline $11-15$ times per month & $2.7 \%$ & $2.3 \%$ & 3 & 3 & \multicolumn{2}{|c|}{$6 / 2.5 \%$} \\
\hline$\geq 16$ times per month & $4.5 \%$ & $7.6 \%$ & 5 & 10 & & \\
\hline \multicolumn{7}{|c|}{$\begin{array}{l}\text { I use PUBMED/MEDLINE or other } \\
\text { databases to search for literature } \\
\text { relevant for clinical practice }\end{array}$} \\
\hline$<1$ time per month & $50.9 \%$ & $55.3 \%$ & 56 & 73 & \multicolumn{2}{|c|}{$129 / 53.3 \%$} \\
\hline 2 - 5 times per month & $32.7 \%$ & $34.8 \%$ & 36 & 46 & \multicolumn{2}{|c|}{$82 / 33.9 \%$} \\
\hline $6-10$ times per month & $10.9 \%$ & $6.8 \%$ & 12 & 9 & \multicolumn{2}{|c|}{$21 / 8.7 \%$} \\
\hline 11 - 15 times per month & $1.8 \%$ & $0.8 \%$ & 2 & 1 & \multicolumn{2}{|c|}{$3 / 1.2 \%$} \\
\hline$\geq 16$ times per month & $3.6 \%$ & $2.3 \%$ & 4 & 3 & \multicolumn{2}{|c|}{$7 / 2.9 \%$} \\
\hline
\end{tabular}

Tab. 2.1 - Respondents' attitude characteristics.

categories: 1) Personal details, 2) Personal attitudes, 3) Skills. Each category consists of several questions and each question has several possibilities of answer (levels). With regard to demographic characteristics, the response options range from 2 to 9, while for attitudes and skills, there are 5 response options (Annex 1). The online platform "Google Forms" was used to fill in the questionnaire and collect the data.
Inclusion criteria: membership in the TSRM-PSTRP order of the two regions. Exclusion criteria: nonmembership in the TSRM-PSTRP order of one of the two regions. The spread of the questionnaire started on 22 December 2020 and it ended on 04 February 2021. Data analysis was carried out using the SPSS 20 version for Microsoft Windows 5. The frequencies of responses to the survey questions were determined 
and displayed in the form of tables and graphs. After examining the frequency of the answers, the inferential analysis of the association among the variables of NON-parametric data of the registry part regarding the two regions (Marche - Umbria) was carried out through the use of the chi-square test (X2). Then, the associations in terms of significant probability $(\mathrm{p}<0.05)$ among the variables of "personal attitudes" and "EBP-related skills" with "demographic characteristics" were examined. The five levels of the categories attitudes and skills were compressed into two levels in order to allow further analysis using them as dependent measures in the logistic regression study as follows: for the response level "Strongly Disagree", "DISAGREE" and "Neutral" the new level is "DISAGREE", for the response level "AGREE" and "Strongly Agree", the new level is "AGREE". After compression, logistic regression, conducted on univariate analysis, was performed to examine the following associations: years of habilitation, educational qualification and age, on the responses of each question. The level of significant difference was set at $\mathrm{P}<0.05$. The Odds Ratio (OR) and the respective $95 \%$ confidence intervals (CI) are also determined for each level of the independent variables in the significant models $(p<0.05)$. The reference group is usually chosen by the researcher at the start of the analysis to allow interpretation of the most salient results. The confidence of the intervals provides information on the precision of the estimated OR. We chose to examine univariate associations rather than multivariate associations to present our information in order to provide a basis for future hypothesis testing.

\section{RESULTS}

242 physiotherapists responded to the survey, of whom 110 from Umbria and 132 from the Marche, with a response rate for Umbria of 12.99\% (847 registered physiotherapists) and $7.64 \%$ for the Marche (1727 registered physiotherapists), Table n.1, Table n.2.1 and Table n.2.2.

For physiotherapists in the Umbria region to the factor of the number of years since obtaining the habilitation "habilitation years", there is a non-random and significant distribution $(\mathrm{p}<0.05)$ for the comparison to the degree of "AGREE" of the answer to the question: "Is the application of EBP necessary in the practice of physiotherapists" equal to a frequency of $32.7 \%$ for the habilitation years "MORE than 15 ", for the answer to the question "EBP helps me to make decisions about the clinical management of patients", there is with a degree of "AGREE" equal to a frequency of $30 \%$ for the habilitation years "MORE

\begin{tabular}{|c|c|c|c|c|c|}
\hline Feature & $\begin{array}{l}\text { Percentage } \\
\text { \% Umbra } \\
\end{array}$ & $\begin{array}{l}\text { Percentage } \\
\% \text { Marche }\end{array}$ & $\begin{array}{l}\text { Number } \\
\text { Umbria }\end{array}$ & $\begin{array}{l}\text { Number } \\
\text { Marche }\end{array}$ & Total number / \% \\
\hline \multicolumn{6}{|c|}{$\begin{array}{l}\text { REVIEW and METANALYSIS } \\
\text { are the studies with the highest } \\
\text { quality of evidence }\end{array}$} \\
\hline Strongly disagree & $1.8 \%$ & $0.8 \%$ & 2 & 1 & $3 / 1.2 \%$ \\
\hline Disagree & $2.7 \%$ & $5.3 \%$ & 3 & 7 & $10 / 4.1 \%$ \\
\hline Neutral & $28.2 \%$ & $40.2 \%$ & 31 & 53 & $84 / 34.7 \%$ \\
\hline Agree & $41.8 \%$ & $37.9 \%$ & 46 & 50 & $96 / 39.7 \%$ \\
\hline Strongly agree & $25.5 \%$ & $15.9 \%$ & 28 & 21 & $49 / 20.2 \%$ \\
\hline \multicolumn{6}{|c|}{$\begin{array}{l}\text { Observational studies have a high } \\
\text { quality of evidence }\end{array}$} \\
\hline Strongly disagree & $7.3 \%$ & $3 \%$ & 8 & 4 & $12 / 5 \%$ \\
\hline Disagree & $32.7 \%$ & $25.8 \%$ & 36 & 34 & $70 / 28.9 \%$ \\
\hline Neutral & $43.6 \%$ & $50 \%$ & 48 & 66 & $114 / 47.1 \%$ \\
\hline Agree & $15.5 \%$ & $21.2 \%$ & 17 & 28 & $45 / 18.6 \%$ \\
\hline Strongly agree & $0.9 \%$ & - & 1 & - & $1 / 0.4 \%$ \\
\hline $\begin{array}{l}\text { Experimental stu } \\
\text { highest quality of }\end{array}$ & & & & & \\
\hline Strongly disagree & $3.6 \%$ & $1.5 \%$ & 4 & 2 & $6 / 2.5 \%$ \\
\hline Disagree & $20 \%$ & $20.5 \%$ & 22 & 27 & $49 / 20.2 \%$ \\
\hline Neutral & $43.6 \%$ & $37.1 \%$ & 48 & 49 & $97 / 40.1 \%$ \\
\hline Agree & $28.2 \%$ & $34.8 \%$ & 31 & 46 & $77 / 31.8 \%$ \\
\hline Strongly agree & $4.5 \%$ & $6.1 \%$ & 5 & 8 & $13 / 5.4 \%$ \\
\hline $\begin{array}{l}\text { Case reports are } \\
\text { effectiveness and } \\
\text { identify new dise } \\
\text { clinical presentat } \\
\text { or unusual preser } \\
\text { diseases. }\end{array}$ & & & & & \\
\hline Strongly disagree & $1.8 \%$ & $3 \%$ & 2 & 4 & $6 / 2.5 \%$ \\
\hline Disagree & $10 \%$ & $9.1 \%$ & 1 & 1 & $23 / 9.5 \%$ \\
\hline Neutral & $34.5 \%$ & $38.6 \%$ & 3 & 5 & $89 / 36.8 \%$ \\
\hline Agree & $47.3 \%$ & $43.2 \%$ & 5 & 5 & $109 / 45 \%$ \\
\hline Strongly agree & $6.4 \%$ & $6.1 \%$ & 7 & 8 & $15 / 6.2 \%$ \\
\hline
\end{tabular}

Tab. 2.2 - Competencies related to EBP. 
than 15". The question "Use of PUBMED/MEDLINE or other databases to search for literature relevant to clinical practice" was answered with a frequency of "LESS THAN ONCE A MONTH" equal to a frequency of $30.9 \%$ for habilitation years "GREATER THAN 15". Concerning the study of the factor "qualification", there is always a non-random and significant distribution $(\mathrm{p}<0.05)$ with the comparison to the degree of "DISAGREE" to the answers of the question: "The adaptation of the practice based on the evidence of the literature is an unreasonable demand for physiotherapists" equal to a frequency of $21.8 \%$ for the title "postgraduate course". To the question "Evidence based practice improves quality of care" there is a degree of "AGREE" with a frequency of "equivalent degree" at 20\%, while a degree of "STRONGLY AGREE" with a frequency of "equivalent degree" of $22.7 \%$ for the question "EBP helps me to make decisions about the clinical management of patients", Table n. 3.

Again, in the Umbria region, physiotherapists aged 3039 years, $44 \%$ of the respondents, were more likely to claim that: "Adaptation of practice based on evidence from the literature is an unreasonable demand for physiotherapists", as were 0.03 times more likely to support this statement, with an inconstant age adjustment (r. 0.19) 6. Physiotherapists aged 4049 years, $25 \%$ of the total survey respondents, are likely to state that their interest is focused on learning or improving the skills necessary to incorporate evidence-based practice, as they were 0.15 times more likely to support this statement, with an inconstant age adjustment (r. 0.21). Physiotherapists with 5-10 years since habilitation, representing 30\% of the total sample respondents, are likely to argue that gains increase if EBP is used in daily practice, as well as being 30.8 times more likely to agree with this statement, with an inconstant adjustment for years of habilitation (r. 0.17). Physiotherapists with "years of habilitation" "LESS than 5", 19\% of the total sample members, claim that "EBP does not take into account patients' preferences”, as well as being 11.4 times more likely to agree with this statement, with a non-constant adjustment for "years of habilitation"

${ }^{6}$ Nagelkerke, Nico J.D. (1992) Maximum Likelihood Estimation of Functional Relationships, Pays-Bas, Lecture Notes in Statistics, Volume 69, 110p ISBN 0-387-97721-X.

\begin{tabular}{|c|c|c|c|c|}
\hline Aptitude & Degree of Agreement & Feature & Level (Fr) & $\mathbf{P} *$ \\
\hline $\begin{array}{l}\text { Application of EBP is } \\
\text { necessary in the practice of } \\
\text { physiotherapists }\end{array}$ & $\begin{array}{l}\text { S. Disagreement } \\
\text { Disagreement } \\
\text { Neutral } \\
\text { Agreement (32.7\%) } \\
\text { S. Agreement }\end{array}$ & Habilitation Years & $\begin{array}{l}<5 \\
5-10 \\
11-15 \\
>\mathbf{1 5}\end{array}$ & $<0.05$ \\
\hline $\begin{array}{l}\text { EBP helps me to make } \\
\text { decisions about the clinical } \\
\text { management of patients }\end{array}$ & $\begin{array}{l}\text { S. Disagreement } \\
\text { Disagreement } \\
\text { Neutral } \\
\text { Agreement (30\%) } \\
\text { S. Agreement }\end{array}$ & Habilitation Years & $\begin{array}{l}<5 \\
5-10 \\
11-15 \\
>\mathbf{1 5}\end{array}$ & $<0.05$ \\
\hline $\begin{array}{l}\text { I use PUBMED/MEDLINE } \\
\text { or other databases to search } \\
\text { for literature relevant to } \\
\text { clinical practice. }\end{array}$ & $\begin{array}{l}<\mathbf{1} \text { Times Month }(\mathbf{3 0 . 9 \% )} \\
2-5 \text { times a month } \\
\text { 6-10 times a month } \\
\text { 11-15 times a month } \\
\geq 16 \text { times per month }\end{array}$ & Habilitation Years & $\begin{array}{l}<5 \\
5-10 \\
11-15 \\
>\mathbf{1 5}\end{array}$ & $<0.05$ \\
\hline $\begin{array}{l}\text { Adaptation of practice } \\
\text { based on evidence from the } \\
\text { literature is an unreasonable } \\
\text { demand for physiotherapists. }\end{array}$ & $\begin{array}{l}\text { S. Disagreement } \\
\text { Disagreement }(\mathbf{2 1 . 8 \% )} \\
\text { Neutral } \\
\text { Agreement } \\
\text { S. Agreement }\end{array}$ & Qualification & $\begin{array}{l}\text { PC } \\
\text { MD } \\
\text { M } 1 \\
\text { M } 2 \\
\text { PhD } \\
\text { ED }\end{array}$ & $<0.05$ \\
\hline $\begin{array}{l}\text { Evidence-based practice } \\
\text { improves quality of care }\end{array}$ & $\begin{array}{l}\text { S. Disagreement } \\
\text { Disagreement } \\
\text { Neutral } \\
\text { Agreement (20\%) } \\
\text { S. Agreement }\end{array}$ & Qualification & $\begin{array}{l}\text { PC } \\
\text { MD } \\
\text { M } 1 \\
\text { M } 2 \\
\text { PhD } \\
\text { ED }\end{array}$ & $<0.05$ \\
\hline $\begin{array}{l}\text { EBP helps me to make } \\
\text { decisions about the clinical } \\
\text { management of patients }\end{array}$ & $\begin{array}{l}\text { S. Disagreement } \\
\text { Disagreement } \\
\text { Neutral } \\
\text { Agreement (22.7\%) } \\
\text { S. Agreement }\end{array}$ & Qualification & $\begin{array}{l}\text { PC } \\
\text { MD } \\
\text { M } 1 \\
\text { M } 2 \\
\text { PhD } \\
\text { ED }\end{array}$ & $<0.05$ \\
\hline
\end{tabular}

Tab. 3 - Comparison between the degree of agreement of attitude and characteristic in the Umbria Region.

Key: < 5: Less than 5 years old, 5-10: Between 5 and 10 years old, 11-15: Between 11 and 15 years old, > 15: Greater than 15 years old, PC: Postgraduate course.

MD: Master's Degree (LM/SNT2), M_1: First Level Master's Degree, M_2: Second Level Master's Degree, ED: Equivalent Degree, * Statistical significance. 


\begin{tabular}{|c|c|c|c|c|c|c|}
\hline Aptitude & Feature & Level & $\begin{array}{l}\text { Reference } \\
\left(95 \% \text { Cl) }{ }^{\text {to }}\right.\end{array}$ & $\begin{array}{c}\text { Model } \\
\mathbf{P}\end{array}$ & $\begin{array}{c}\text { Model } \\
\mathbf{R}^{2, c}\end{array}$ & $\mathbf{N}$ \\
\hline $\begin{array}{l}\text { Adaptation of } \\
\text { evidence-based } \\
\text { practice is an } \\
\text { unreasonable demand } \\
\text { for physiotherapists }\end{array}$ & Age & $\begin{array}{l}20-29 \\
30-39 \\
40-49 \\
<50\end{array}$ & $\begin{array}{l}0.1(0-0.6) \\
0.1(0-0.6) \\
0.6(0.1-2.8) \\
\text { Reference }^{\mathrm{b}}\end{array}$ & .021 & .19 & 110 \\
\hline $\begin{array}{l}\text { I am interested in } \\
\text { learning or improving } \\
\text { the skills needed to } \\
\text { incorporate evidence- } \\
\text { based practice. }\end{array}$ & Age & $\begin{array}{l}20-29 \\
30-39 \\
40-49 \\
<50\end{array}$ & $\begin{array}{l}0.6(0.1-16.2) \\
0.3(0.1-2.3) \\
0.1(0-0.6) \\
\text { Reference }^{\mathrm{b}}\end{array}$ & .011 & .21 & 110 \\
\hline $\begin{array}{l}\text { My gains increase if I } \\
\text { use EBP in my daily } \\
\text { practice }\end{array}$ & $\begin{array}{l}\text { Habilitation } \\
\text { Years }\end{array}$ & $\begin{array}{l}<5 \\
5-10 \\
11-15 \\
>15\end{array}$ & $\begin{array}{l}28.6(1.4-6.1) \\
30.8(1.5-6.3) \\
19.1(0.9-3.6) \\
\text { Reference }^{b}\end{array}$ & .026 & .17 & 110 \\
\hline $\begin{array}{l}\text { EBP does not take } \\
\text { patient preferences into } \\
\text { account }\end{array}$ & $\begin{array}{l}\text { Habilitation } \\
\text { Years }\end{array}$ & $\begin{array}{l}<5 \\
5-10 \\
11-15 \\
>15\end{array}$ & $\begin{array}{l}11.3(1.3-10.2) \\
4.8(0.7-33.6) \\
3.8(0.6-23.7) \\
\text { Reference }^{\mathrm{b}}\end{array}$ & .030 & .13 & 110 \\
\hline
\end{tabular}

Tab. 4.1 - Associated characteristics of attitudes in the use of EBP, Umbria.

Key: 20-29: Age between 20 and 29 years, 30-39: Age between 30-39 years, 40-49: Age between 40-49 years, < 50: Age over 50 years, $<5$ : Under 5 years, 5-10: Between 5 and 10 years,

11-15: Between 11 and 15 years, $>15$ : Greater than 15 years, a 95\% CI $=95 \%$ confidence interval. $\mathrm{b}$ In logistic regression, one level of the independent variable serves as a reference against which the probability of occurrence of the other levels is determined. $\mathrm{c}^{\text {Nagelkerke }} \mathrm{R} 2$.

\begin{tabular}{|c|c|c|c|c|c|c|}
\hline Skills & Feature & Level & $\begin{array}{l}\text { Reference } \\
(95 \% \text { Cl) }\end{array}$ & $\begin{array}{c}\text { Model } \\
\mathbf{P}\end{array}$ & $\begin{array}{c}\text { Model } \\
\mathbf{R}^{2, \mathrm{c}}\end{array}$ & $\mathbf{N}$ \\
\hline $\begin{array}{l}\text { Review and } \\
\text { meta-analysis } \\
\text { are the } \\
\text { studies with } \\
\text { the highest } \\
\text { quality of } \\
\text { evidence. }\end{array}$ & Qualification & $\begin{array}{l}\mathrm{PC} \\
\mathrm{MD} \\
\mathrm{M} \_1 \\
\mathrm{M} 2 \\
\mathrm{PhD} \\
\mathrm{ED}\end{array}$ & $\begin{array}{l}0.1(0-0.3) \\
0.8(0.2-2.9) \\
1.2(0.3-4.0) \\
- \\
- \\
\text { Reference }^{\mathrm{b}}\end{array}$ & .000 & .47 & 110 \\
\hline
\end{tabular}

Tab. 4.2 - Characteristics associated with EBP knowledge competencies, Umbria.

Key: PC: Postgraduate course, MD: Master's degree (LM/SNT2), M1: First Level Master's Degree, M2: Second Level Master's degree, ED: Equivalent degree, ${ }^{\mathrm{a}} 95 \% \mathrm{CI}=95 \%$ confidence interval. ${ }^{\mathrm{b}}$ In logistic regression, one level of the independent variable serves as a reference against which the probability of occurrence of the other levels is determined. ${ }^{c}$ Nagelkerke R2.

(r. 0.13). The physiotherapists who carried out "postgraduate courses", 44\% of the Umbrians participating in the survey, sustain that "REVIEW and METHANALYSIS are the studies that have the highest quality of evidence", just as they are 0.1 times more likely to defend this statement, even if the factor of "educational qualification" does not have a linear fit (r. 0.46), Table n. 4.1 and Table n. 4.2.

For the physiotherapists of the Marche region to the factor of the number of years since obtaining the habilitation " habilitation years" there is a nonrandom and significant distribution $(\mathrm{p}<0.05)$ with the comparison to the degree of agreement "NEUTRAL" for the answers to the question: "EBP does not take patient preferences into account" equal to a frequency of $47.5 \%$ for habilitation years "GREATER than 15 ", this is also valid for the answers to the questions: "Reviews and meta-analysis are the studies that have the highest quality of evidence", equal to a frequency of $39 \%$ for habilitation years "GREATER than 15 ". For the question "Observational studies have a high quality of evidence" there is a frequency of $52.5 \%$ for "Years of habilitation" with a degree of agreement of "MORE than 15". While for the question "Case reports are usually used to check efficacy and risks of treatments, to identify new diseases, to recognize clinical presentations of rare diseases or unusual presentations of common diseases", there is a degree of "STRONGLY AGREE" with a frequency of $50.7 \%$ for the years of habilitation "GREATER than 15". With regard to the factor "educational qualification" there is always a non-random and significant distribution $(\mathrm{p}<0.05)$ with the comparison to the degree of "AGREE" for the answers to the question: "The application of EBP is necessary in the practice of physiotherapists" equal to a frequency of $17.42 \%$ for the title "postgraduate course". For the question "Adaptation of practice based on evidence from the literature is an unreasonable demand for physiotherapists" there is the degree of "DISAGREE" equal to a frequency of $16.67 \%$ for the title "postgraduate course", for the question "EBP does 


\begin{tabular}{|c|c|c|c|c|}
\hline Aptitude & Degree of AGREEMENT & Feature & Level (FR) & $\mathbf{P}^{*}$ \\
\hline $\begin{array}{l}\text { EBP helps me to make decisions about } \\
\text { the clinical management of patients }\end{array}$ & $\begin{array}{l}\text { S. Disagreement } \\
\text { Disagreement } \\
\text { Neutral } \\
\text { Agreement (23.5\%) } \\
\text { S. Agreement }\end{array}$ & $\begin{array}{l}\text { Habilitation } \\
\text { Years }\end{array}$ & $\begin{array}{l}<5 \\
5-10 \\
11-15 \\
>\mathbf{1 5}\end{array}$ & $<0.05$ \\
\hline $\begin{array}{l}\text { REVIEW and METANALYSIS are } \\
\text { the studies with the highest quality of } \\
\text { evidence }\end{array}$ & $\begin{array}{l}\text { S. Disagreement } \\
\text { Disagreement } \\
\text { Neutral (25\%) } \\
\text { Agreement } \\
\text { S. Agreement }\end{array}$ & $\begin{array}{l}\text { Habilitation } \\
\text { Years }\end{array}$ & $\begin{array}{l}<5 \\
5-10 \\
11-15 \\
>\mathbf{1 5}\end{array}$ & $<0.05$ \\
\hline $\begin{array}{l}\text { Observational studies have a high } \\
\text { quality of evidence. }\end{array}$ & $\begin{array}{l}\text { S. Disagreement } \\
\text { Disagreement } \\
\text { Neutral } \\
\text { Agreement (28\%) } \\
\text { S. Agreement }\end{array}$ & $\begin{array}{l}\text { Habilitation } \\
\text { Years }\end{array}$ & $\begin{array}{l}<5 \\
5-10 \\
11-15 \\
>\mathbf{1 5}\end{array}$ & $<0.05$ \\
\hline $\begin{array}{l}\text { Case reports are usually used to check } \\
\text { effectiveness and risks of treatments, } \\
\text { identify new diseases, recognize } \\
\text { clinical presentations of rare diseases } \\
\text { or unusual presentations of common } \\
\text { diseases. }\end{array}$ & $\begin{array}{l}\text { S. Disagreement } \\
\text { Disagreement } \\
\text { Neutral } \\
\text { Agreement (25.8\%) } \\
\text { S. Agreement }\end{array}$ & $\begin{array}{l}\text { Habilitation } \\
\text { Years }\end{array}$ & $\begin{array}{l}<5 \\
5-10 \\
11-15 \\
>\mathbf{1 5}\end{array}$ & $<0.05$ \\
\hline $\begin{array}{l}\text { Application of EBP is necessary in the } \\
\text { practice of physiotherapists }\end{array}$ & $\begin{array}{l}\text { S. Disagreement } \\
\text { Disagreement } \\
\text { Neutral } \\
\text { Agreement (17.4\%) } \\
\text { S. Agreement }\end{array}$ & Qualification & $\begin{array}{l}\text { PC } \\
\text { MD } \\
\text { M_1 } \\
\text { M_2 } \\
\text { PhD } \\
\text { ED }\end{array}$ & $<0.05$ \\
\hline $\begin{array}{l}\text { Adaptation of practice based } \\
\text { on evidence of the literature is } \\
\text { an unreasonable demand for } \\
\text { physiotherapists. }\end{array}$ & $\begin{array}{l}\text { S. Disagreement } \\
\text { Disagreement (16.7\%) } \\
\text { Neutral } \\
\text { Agreement } \\
\text { S. Agreement }\end{array}$ & Qualification & $\begin{array}{l}\text { PC } \\
\text { MD } \\
\text { M_1 } \\
\text { M_2 } \\
\text { PhD } \\
\text { ED }\end{array}$ & $<0.05$ \\
\hline $\begin{array}{l}\text { EBP does NOT take patient preferences } \\
\text { into account }\end{array}$ & $\begin{array}{l}\text { S. Disagreement } \\
\text { Disagreement } \\
\text { Neutral }(\mathbf{1 4 . 4 \% )} \\
\text { Agreement } \\
\text { S. Agreement }\end{array}$ & Qualification & $\begin{array}{l}\text { PC } \\
\text { MD } \\
\text { M_1 } \\
\text { M_2 } \\
\text { PhD } \\
\text { ED }\end{array}$ & $<0.05$ \\
\hline $\begin{array}{l}\text { Use of research results in the clinical/ } \\
\text { decision-making process. }\end{array}$ & $\begin{array}{l}<1 \text { Times Month } \\
\mathbf{2 - 5} \text { Times per month } \\
\mathbf{( 1 8 . 9 \% )} \\
6-10 \text { times a month } \\
11-15 \text { times a month } \\
>16 \text { times a month }\end{array}$ & Qualification & $\begin{array}{l}\text { PC } \\
\text { MD } \\
\text { M_1 } \\
\text { M_2 } \\
\text { PhD } \\
\text { ED }\end{array}$ & $<0.05$ \\
\hline $\begin{array}{l}\text { I use PUBMED/MEDLINE or other } \\
\text { databases to search for literature } \\
\text { relevant to clinical practice. }\end{array}$ & $\begin{array}{l}<\mathbf{1} \text { Times Month }(\mathbf{2 0 . 4 \% )} \\
\text { 2-5 times a month } \\
\text { 6-10 times a month } \\
\text { 11-15 times a month } \\
>16 \text { times a month }\end{array}$ & Qualification & $\begin{array}{l}\text { PC } \\
\text { MD } \\
\text { M_1 } \\
\text { M_2 } \\
\text { PhD } \\
\text { ED }\end{array}$ & $<0.05$ \\
\hline $\begin{array}{l}\text { REVIEW and METANALYSIS are } \\
\text { the studies with the highest quality of } \\
\text { evidence }\end{array}$ & $\begin{array}{l}\text { S. Disagreement } \\
\text { Disagreement } \\
\text { Neutral }(\mathbf{1 9 . 7 \% )} \\
\text { Agreement } \\
\text { S. Agreement }\end{array}$ & Qualification & $\begin{array}{l}\text { PC } \\
\text { MD } \\
\text { M_1 } \\
\text { M_2 } \\
\text { PhD } \\
\text { ED }\end{array}$ & $<0.05$ \\
\hline $\begin{array}{l}\text { Case reports are usually used to check } \\
\text { effectiveness and risks of treatments, } \\
\text { identify new diseases, recognize } \\
\text { clinical presentations of rare diseases } \\
\text { or unusual presentations of common } \\
\text { diseases. }\end{array}$ & $\begin{array}{l}\text { S. Disagreement } \\
\text { Disagreement } \\
\text { Neutral (18.9\%) } \\
\text { Agreement } \\
\text { S. Agreement }\end{array}$ & Qualification & $\begin{array}{l}\text { PC } \\
\text { MD } \\
\text { M_1 } \\
\text { M_2 } \\
\text { PhD } \\
\text { ED }\end{array}$ & $<0.05$ \\
\hline
\end{tabular}

Tab. 5 - Comparison between the degree of agreement of aptitude and characteristic in the Marche Region.

Key: < 5: Less than 5 years, 5-10: Between 5 and 10 years, 11-15: Between 11 and 15 years, > 15: More than 15 years, PC: Postgraduate course, MD: Master's degree, M_1: First Level Master's degree, M_2: Second Level Master's degree, ED: Equivalent degree, ${ }^{*}$ Statistical significance $(\mathrm{P}<0.05)$. 
NOT take into account patients' preferences" there is the degree of "NEUTRAL" equal to a frequency of $14.39 \%$ for "the equivalent degree". for the question "Use of research results in the clinical/decisionmaking process" the level grade is "DISAGREE" with an attendance of $18.94 \%$ for the "Use of PUBMED/MEDLINE or other databases to search for literature relevant to clinical practice" the level grade is "STRONGLY DISAGREE" with an attendance of $20.45 \%$ for the "Advanced training course", for the question "REVIEW and METANALYSIS are the studies that have the highest quality of evidence" we have the level grade "NEUTRAL" corresponding to a "postgraduate course" frequency of 19.70, for the question "Case reports are usually used to check efficacy and risks of treatments, to identify new diseases, to recognize clinical presentations of rare diseases or unusual presentations of common diseases" we have the level grade "NEUTRAL" corresponding to a "postgraduate course" frequency of $18.94 \%$, Table no. 5.5 .

Again, in the Marche region, physiotherapists with a "postgraduate course", who represent $64 \%$ of the total respondents, are the most likely to claim that "they are interested in learning or improving the skills necessary to incorporate evidence-based practice", as well as they were 0.2 times more likely to support this statement, with a non-constant age adjustment (r. 0.16). Physiotherapists aged 40 - 49 years, representing $47 \%$ of the total respondents, are the most likely to say that "Evidence-based practice does NOT take into account the limitations of their rehabilitation setting", as well as they were 2.84 times more likely to support this statement with a non-constant age adjustment (r. 0.12). Physiotherapists with "Master's degree (LM/ SNT2)", $43 \%$ of the total respondents, were the most likely to agree that "EBP helps me to make decisions about the clinical management of patients" as well as they were 3.30 times more likely to support this statement, with a non-constant adjustment of the qualification “Master's degree (LM/SNT2)" (r.0.17). Physiotherapists with ages $40-49$, representing $47 \%$ of respondents, were the most likely to agree that " $E B P$ does NOT take into account patient preferences" as well as they were 3.0 times more likely to support this statement, with a non-constant age adjustment (r. 0.1). Physiotherapists with "postgraduate course", representing $64 \%$ of the respondents, were the most likely to agree that "Reviews and Meta-analysis are the studies with the highest quality of evidence", as well as they were 0.213 times more likely to support this statement, with an inconsistent adjustment for “ postgraduate course” (r. 0.26). Physiotherapists with

\begin{tabular}{|c|c|c|c|c|c|c|}
\hline Aptitude & Feature & Level & $\begin{array}{l}\text { Reference } \\
(95 \% \text { Cl })^{\text {to }}\end{array}$ & $\begin{array}{c}\text { Model } \\
\text { P }\end{array}$ & $\begin{array}{c}\text { Model } \\
\mathbf{R}^{2, \mathrm{c}}\end{array}$ & $\mathbf{N}$ \\
\hline $\begin{array}{l}\text { I am interested } \\
\text { in learning or } \\
\text { improving the skills } \\
\text { needed to incorporate } \\
\text { evidence-based } \\
\text { practice }\end{array}$ & Qualification & $\begin{array}{l}\mathrm{PC} \\
\mathrm{MD} \\
\mathrm{M} \_1 \\
\mathrm{M} \_2 \\
\mathrm{PhD} \\
\mathrm{ED}\end{array}$ & $\begin{array}{l}0.1(0-0.6) \\
0.6(0.1-2.4) \\
1.3(0.2-7.5) \\
- \\
- \\
\text { Reference }^{b}\end{array}$ & .004 & .16 & 132 \\
\hline $\begin{array}{l}\text { Evidence-based } \\
\text { practice does NOT } \\
\text { take into account the } \\
\text { limitations of my } \\
\text { rehabilitation setting }\end{array}$ & Age & $\begin{array}{l}20-29 \\
30-39 \\
40-49 \\
>50\end{array}$ & $\begin{array}{l}2.6(0.6-12.3) \\
1.2(0.4-4.2) \\
2.8(1.3-6.4) \\
\text { Reference }^{\mathrm{b}}\end{array}$ & .012 & .12 & 132 \\
\hline $\begin{array}{l}\text { EBP helps me to } \\
\text { make decisions } \\
\text { about the clinical } \\
\text { management of } \\
\text { patients. }\end{array}$ & Qualification & $\begin{array}{l}\mathrm{PC} \\
\mathrm{MD} \\
\mathrm{M} \_1 \\
\mathrm{M} \_2 \\
\mathrm{PhD} \\
\mathrm{ED}\end{array}$ & $\begin{array}{l}1.1(0.5-2.2) \\
3.3(1.3-8.6) \\
1.5(0.7-3.5) \\
- \\
- \\
\text { Reference }^{b}\end{array}$ & .015 & .17 & 132 \\
\hline $\begin{array}{l}\text { EBP does NOT take } \\
\text { patient preferences } \\
\text { into account }\end{array}$ & Age & $\begin{array}{l}20-29 \\
30-39 \\
40-49 \\
>50\end{array}$ & $\begin{array}{l}0.3(0.0-1.6) \\
1.0(0.3-3.7) \\
3.0(1.3-6.9) \\
\text { Reference }^{\mathrm{b}}\end{array}$ & .010 & .11 & 132 \\
\hline
\end{tabular}

Tab. 6.1 - Characteristics associated with aptitudes towards the use of EBP, Marche.

Key: 20-29: Age between 20 and 29 years, 30-39: Age between 30-39 years, 40-49: Age between 40-49 years, < 50: Age over 50 years, PC: Postgraduate course, MD: Master's degree (LM/SNT2), M1: First Level Master's degree, M2: Second Level Master's degree, ED: Equivalent degree. ${ }^{a}$ 95\% CI $=95 \%$ confidence interval. ${ }^{b}$ In logistic regression, one level of the independent variable serves as a reference against which the probability of occurrence of the other levels is determined. Nagelkerke R2. 
ages $30-39$, representing $73 \%$ of the respondents, were the most likely to agree that "Observational studies have high quality of evidence", as were 0.12 times more likely to support this statement, with a non-constant age adjustment (r. 0.15). Physiotherapists with a First Level Master's degree, $52 \%$ of respondents, were the most likely to agree that "Case reports are used to check efficacy and risks of treatments, identify diseases, recognize rare diseases or common diseases", as well as they were 2.55 times more likely to support this statement, with a non-constant age adjustment (r. 0.92), Table 6.1 and Table 6.2 .

\section{DISCUSSION}

The distribution of qualifications is not the same between the two regions: it can be noticed that in the Umbria region there are more Master's degrees (LM/ SNT2) and Second Level Masters than in the Marche region. Umbria has more physiotherapists without reconversion of the qualification $(16.60 \%)$ than Marche (15.29\%). In the Marche region there are more physiotherapists with advanced postgraduate courses, but these data do not reach statistical significance. This factor is probably linked to the low number of participants in the cognitive survey, Graph n.1. The analysis carried out suggest that physiotherapists in the region of Umbria, with professional qualifications obtained more than 15 years ago, agree that: the application of EBP is necessary in the practice of physiotherapists, Graph n.2; EBP helps in making decisions about the clinical management of patients, Graph n.3; they use search engines, such as PUBMED/ MEDLINE, or other databases for literature searches less than once a month, Graph n.4. Furthermore, holders of equivalent qualifications agree that EBPbased practice improves quality of care, Graph 5 , and that it can help in making decisions about the clinical management of patients, Graph 6. These statements show statistical significance $(\mathrm{p}<0.05)$. Looking at the subgroups, we can notice that Umbrians, aged 3039 years, are more likely to say that the adjustment of evidence-based practice from the literature is an unreasonable demand for physiotherapists. Colleagues aged 40-49 were more likely to state their interest in learning or improving the skills needed to incorporate evidence-based practice. Looking at the subgroups by years of habilitation, those with 5 to 10 years of habilitation are more likely to say that gains increase if they use EBP in clinical practice; those with less than 5 years of habilitation are more likely to say that EBP does not take patient preferences into account. Like their Umbrian colleagues, physiotherapists from the Marche region who have been achieved a habilitation for more than 15 years agreed that EBP helps in making decisions about the clinical management of patients, Graph $7(\mathrm{p}<0.05)$. Those with an equivalent qualification use search engines such as PUBMED/MEDLINE or other databases for literature searches less than once a month, Graph 8; $(\mathrm{p}<0.05)$. Differently for their colleagues in the Umbria region, physiotherapists in the Marche region, with more than 15 years of qualification, agreed that case reports are used to check the efficiency and risks of treatments, identify new diseases, recognize clinical presentations of rare diseases or unusual presentations of common diseases, Graph n.9; $(\mathrm{p}<0.05)$. Referring to the qualification "Postgraduate courses" there is

\begin{tabular}{|c|c|c|c|c|c|c|}
\hline Skills & Feature & Level & $\begin{array}{l}\text { Reference } \\
(95 \% \mathrm{Cl})^{\text {to }}\end{array}$ & $\begin{array}{c}\text { Model } \\
\text { P }\end{array}$ & $\begin{array}{c}\text { Model } \\
\mathbf{R}^{2, \mathrm{c}}\end{array}$ & $\mathbf{N}$ \\
\hline $\begin{array}{l}\text { Reviews and } \\
\text { meta-analysis are } \\
\text { the studies with } \\
\text { the highest quality } \\
\text { of evidence. }\end{array}$ & Qualification & $\begin{array}{l}\mathrm{PC} \\
\mathrm{MD} \\
\mathrm{M} \_1 \\
\mathrm{M}_{-} 2 \\
\mathrm{PhD} \\
\mathrm{ED}\end{array}$ & $\begin{array}{l}0.1(0-0.3) \\
0.8(0.2-.2 .9) \\
1.2(0.4-4.1) \\
- \\
- \\
\text { Reference }^{\mathrm{b}}\end{array}$ & .000 & .47 & 110 \\
\hline $\begin{array}{l}\text { Observational } \\
\text { studies have a } \\
\text { high quality of } \\
\text { evidence }\end{array}$ & Age & $\begin{array}{l}20-29 \\
30-39 \\
40-49 \\
>50\end{array}$ & $\begin{array}{l}0.2(0.1-1.9) \\
0.1(0.1-0.8) \\
1.9(0.9-4.3) \\
\text { Reference }^{\mathrm{b}}\end{array}$ & .034 & .16 & 132 \\
\hline $\begin{array}{l}\text { Case reports are } \\
\text { used to check } \\
\text { effectiveness } \\
\text { and risks of } \\
\text { treatments, } \\
\text { identify diseases, } \\
\text { recognize rare } \\
\text { diseases or } \\
\text { common diseases }\end{array}$ & Qualification & $\begin{array}{l}\text { PC } \\
\text { MD } \\
\text { M_1 } \\
\text { M_2 } \\
\text { PhD } \\
\text { ED }\end{array}$ & $\begin{array}{l}1.1(0.6-2.2) \\
1.4(0.7-3.1) \\
2.6(1.2-5.5) \\
- \\
- \\
\text { Reference }^{b}\end{array}$ & .016 & .09 & 132 \\
\hline
\end{tabular}

Tab. 6.2 - Characteristics associated with EBP knowledge competences, Marche.

Key: 20-29: Age between 20 and 29 years, 30-39: Age between 30-39 years, 40-49: Age between 40-49 years, < 50: Age over 50 years, PC: Postgraduate course, MD: Master's degree (LM/SNT2), M1: First Level Master's degree, M2: Second Level Master's degree, ED: Equivalent degree. ${ }^{a 95} \% \mathrm{CI}=95 \%$ confidence interval. ${ }^{\mathrm{b}}$ In logistic regression, one level of the independent variable serves as a reference against which the probability of occurrence of the other levels is determined. ${ }^{c}$ Nagelkerke R2. 
statistical significance $(\mathrm{p}<0.05)$ for the agreement that the application of EBP is necessary in the practice of physiotherapists and that the results of EBP research involve clinical decision process, with a frequency of 2-5 times per month. Considering the subgroups by age group, it can be noticed that physiotherapists in the Marche region, aged 40-49 years, are more likely to sustain that evidence-based practice does not take into account the limitations of the rehabilitation setting. The same applies to the statement that EBP does not take into account patient preferences. In the subgroup by educational qualification, those with postgraduate courses are more likely to learn and improve the skills needed to incorporate evidence-based practice, while those with a Master degree (LM/SNT2) are more likely to accept that EBP helps in making decisions about the clinical management of patients. Overall, physiotherapists from both regions stated that they were in agreement and had a positive attitude towards the importance of using EBP. In fact, colleagues from both regions consider EBP useful in clinical practice, an element of implementation of their professional knowledge and a factor of better quality of care. Furthermore, they do not consider the application of EBP as an unreasonable proposal for physiotherapists. Both groups expressed impartiality on whether EBP can take into account patients' preferences or not, Graph n.10. The survey reports very interesting data, indicating that the profession requires both research methodology skills and clinical judgement, defining EBP as the integration of research-based evidence with clinical skills. Moreover, it can be deduced that knowledge of EBP differs according to level of education, years of qualification and work context. These data, although with a low sample size, are in line with other works in the literature such as Iles R. et al. ${ }^{16}$, Nilsagård $\mathrm{Y}$ et al. ${ }^{17}$.

\section{CONCLUSIONS}

The physiotherapists who participated in the questionnaire stated that they had a generally positive attitude towards EBP and were interested in

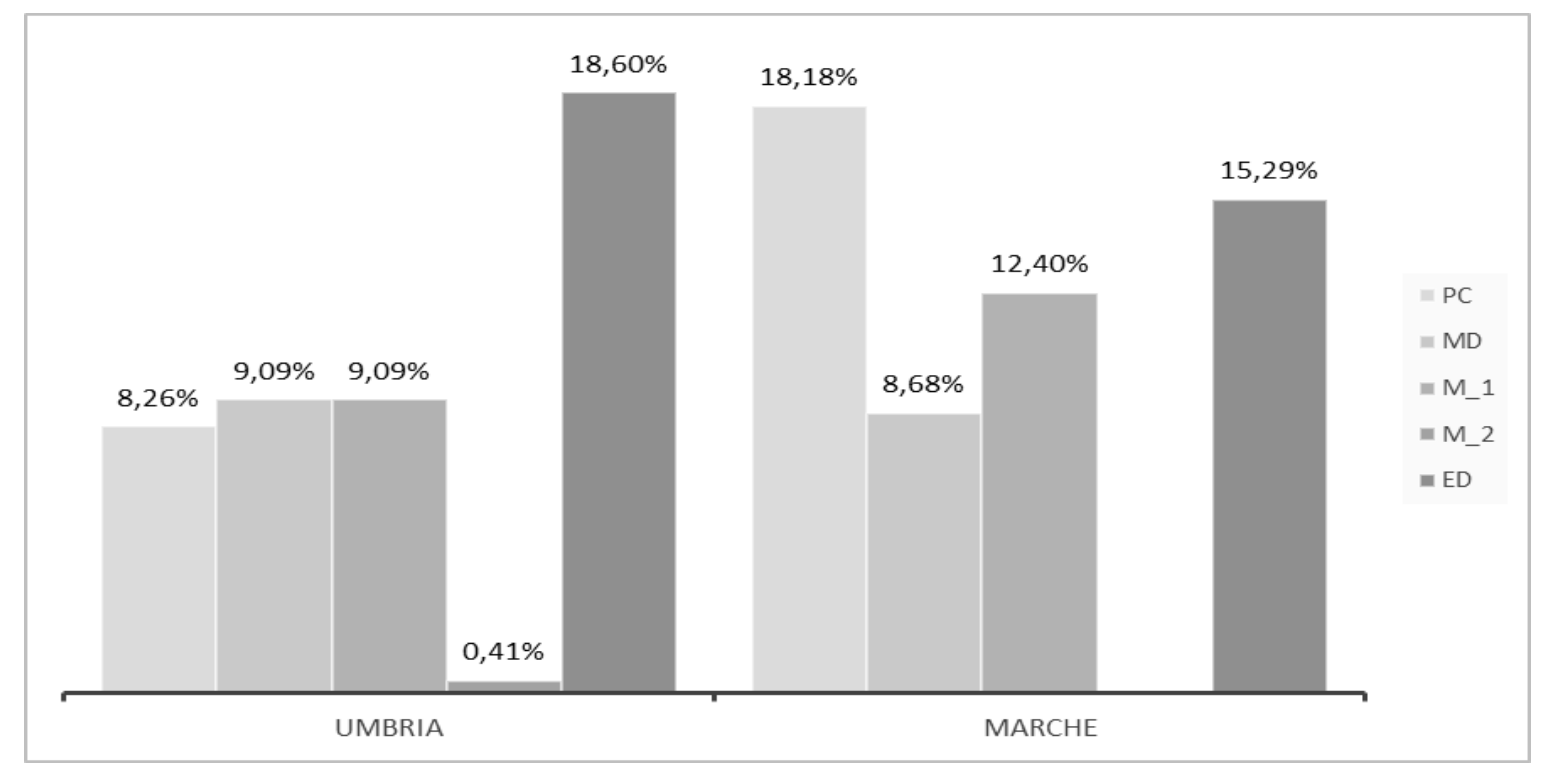

Graph 1 - Distribution of "Educational qualifications" in the two REGIONS.

Key: PC: Postgraduate course, MD: Master's degree (LM/SNT2), M_1: Master's degree (1st level), M_2: Master's degree (2nd level), ED: Equivalent degree.

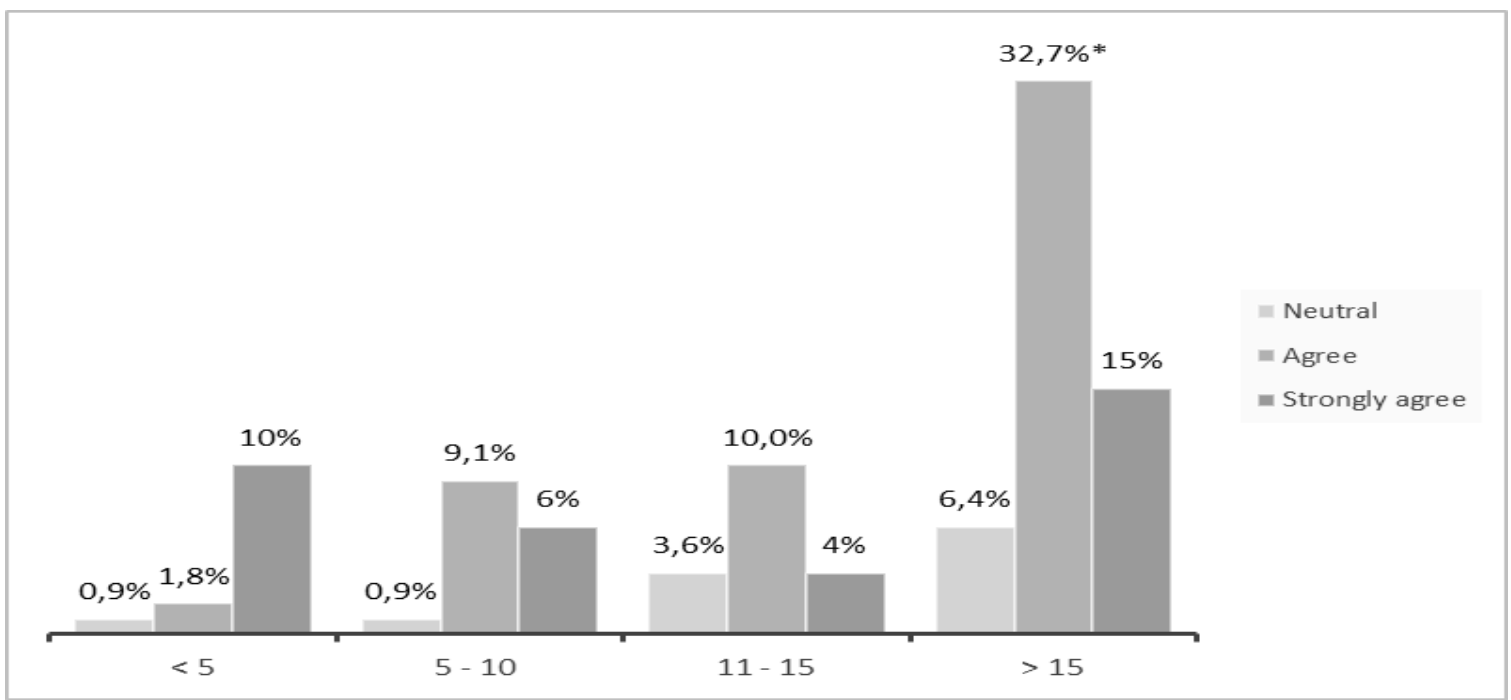

Graph 2 - Distribution of the answers to the question: "Is the application of EBP necessary in the practice of physiotherapists" with compared to "Years of Habilitation", UMBRIA.

Key: < 5: Less than 5 years, 5-10: Between 5 and 10 years, 11-15: Between 11 and 15 years, > 15: Greater than 15 years, *: Statistical significance $(\mathrm{p}<0.05)$. 


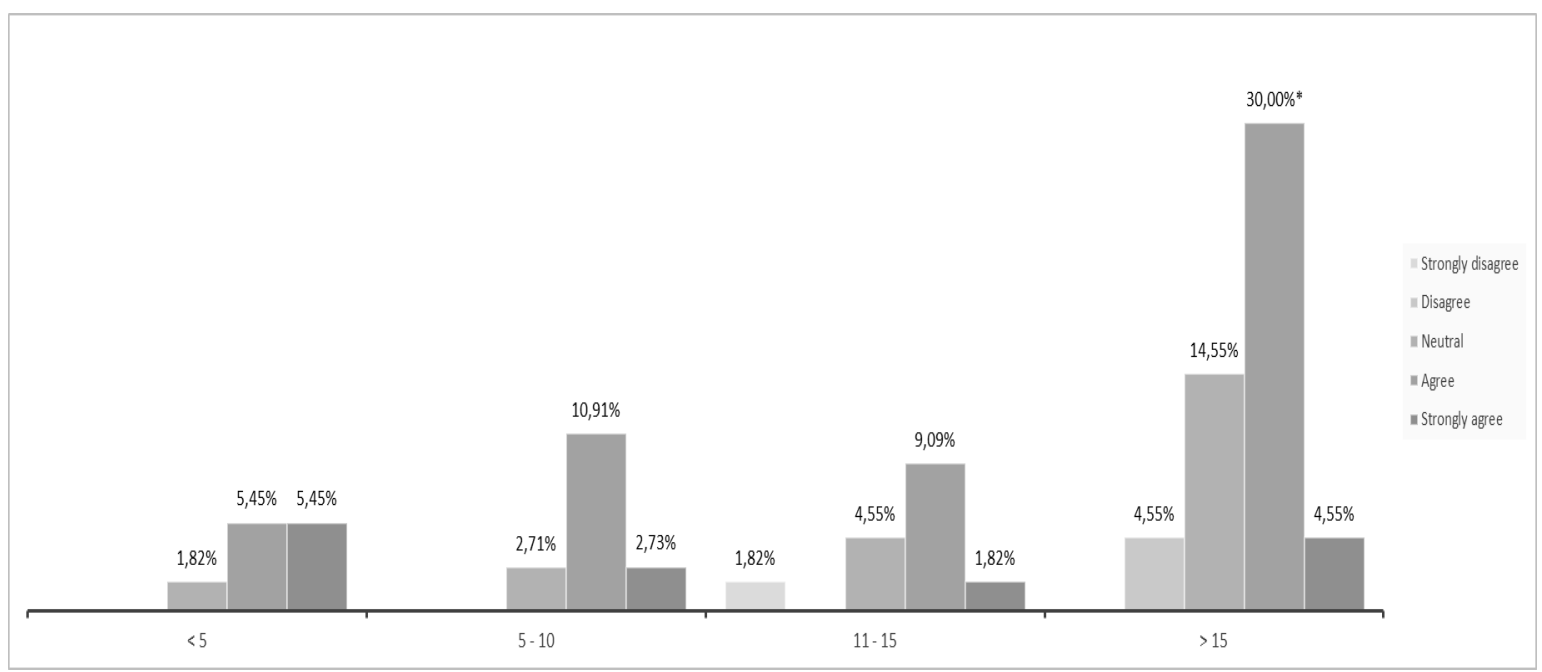

Graph 3 - Distribution of answers to the question: "EBP helps me to make decisions about the clinical management of patients" compared to "years of Habilitation". UMBRIA.

Key: < 5: Less than 5 years, 5-10: Between 5 and 10 years, 11-15: Between 11 and 15 years, > 15: Greater than 15 years, *: Statistical significance $(\mathrm{p}<0.05)$.

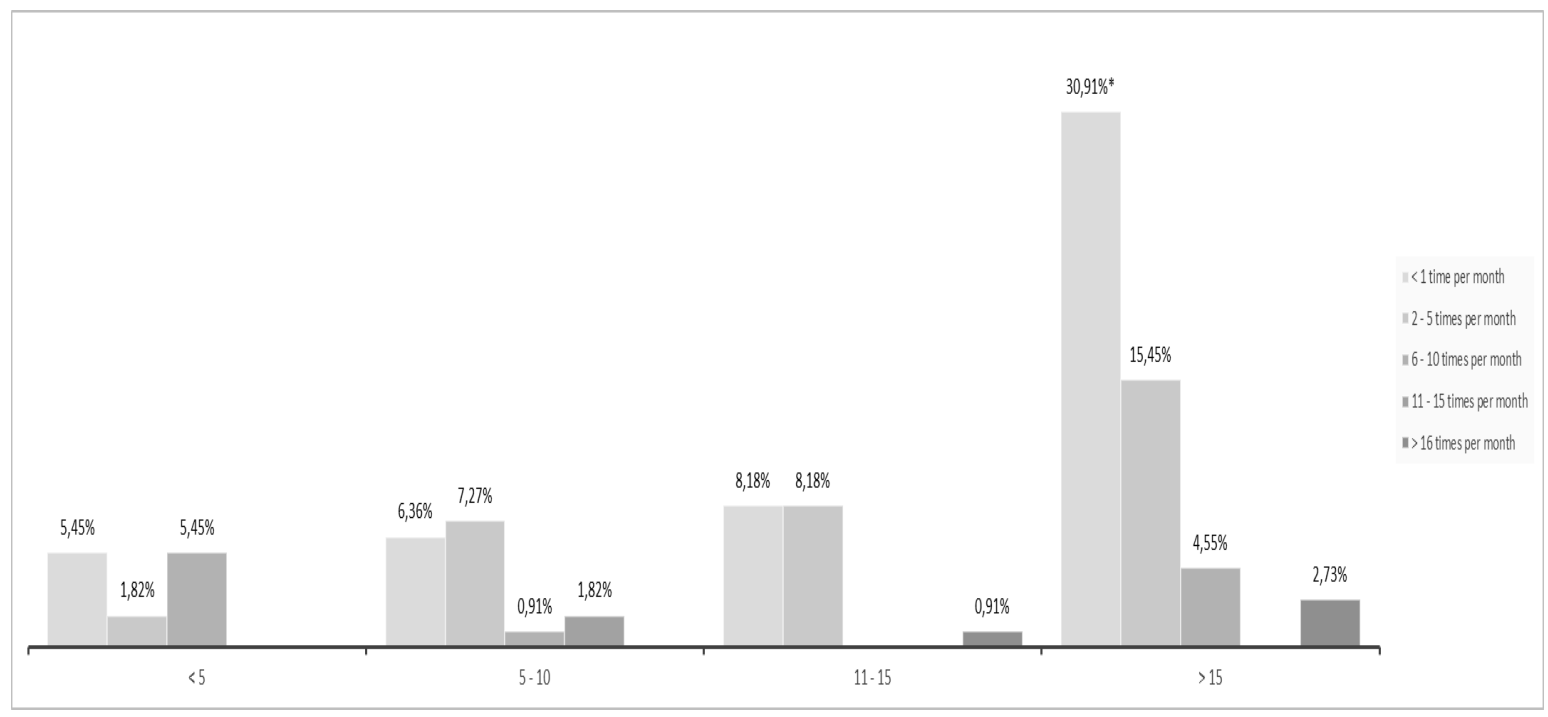

Graph 4 - Distribution of answers to the question: "I use PUBMED/MEDLINE or other databases to search for literature relevant to clinical practice" compared to "Years of Habilitation". UMBRIA.

Key: < 5: Less than 5 years, 5-10: Between 5 and 10 years, 11-15: Between 11 and 15 years, > 15: Greater than 15 years, *: Statistical significance $(\mathrm{p}<0.05)$.

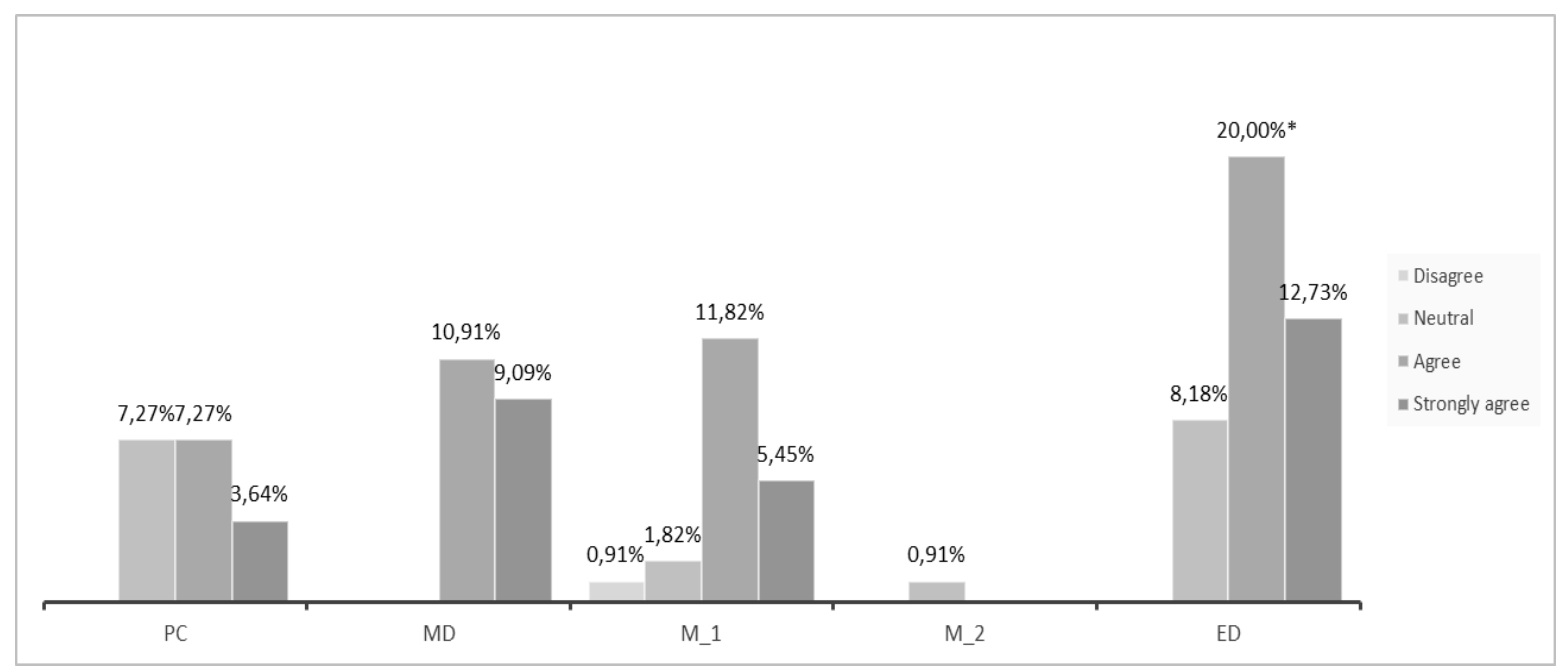

Graph 5 - Distribution of the answers to the question: "Evidence-based practice improves the quality of care" with respect to "Educational qualification", UMBRIA.

Key: PC: Postgraduate course, MD: Master's degree (LM/SNT2), M 1: Master's degree (1st level), M 2: Master's degree (2nd level), ED: Equivalent degree. 


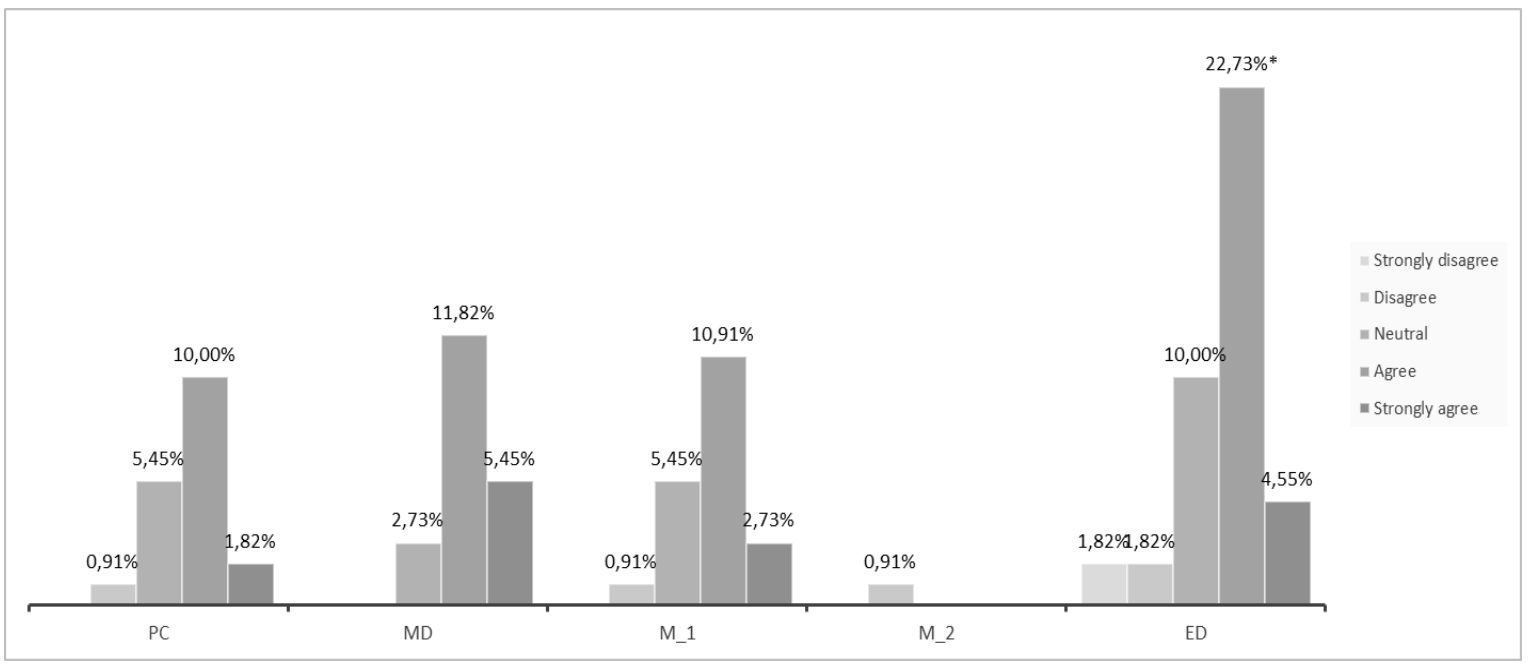

Graph 6 - Distribution of responses to the question: "EBP helps me to make decisions about the clinical management of patients" compared to "Educational qualification", UMBRIA.

Key: PC: Postgraduate course, MD: Master's degree (LM/SNT2), M_1: Master's degree (1st level), M_2: Master's degree (2nd level), ED: Equivalent degree.

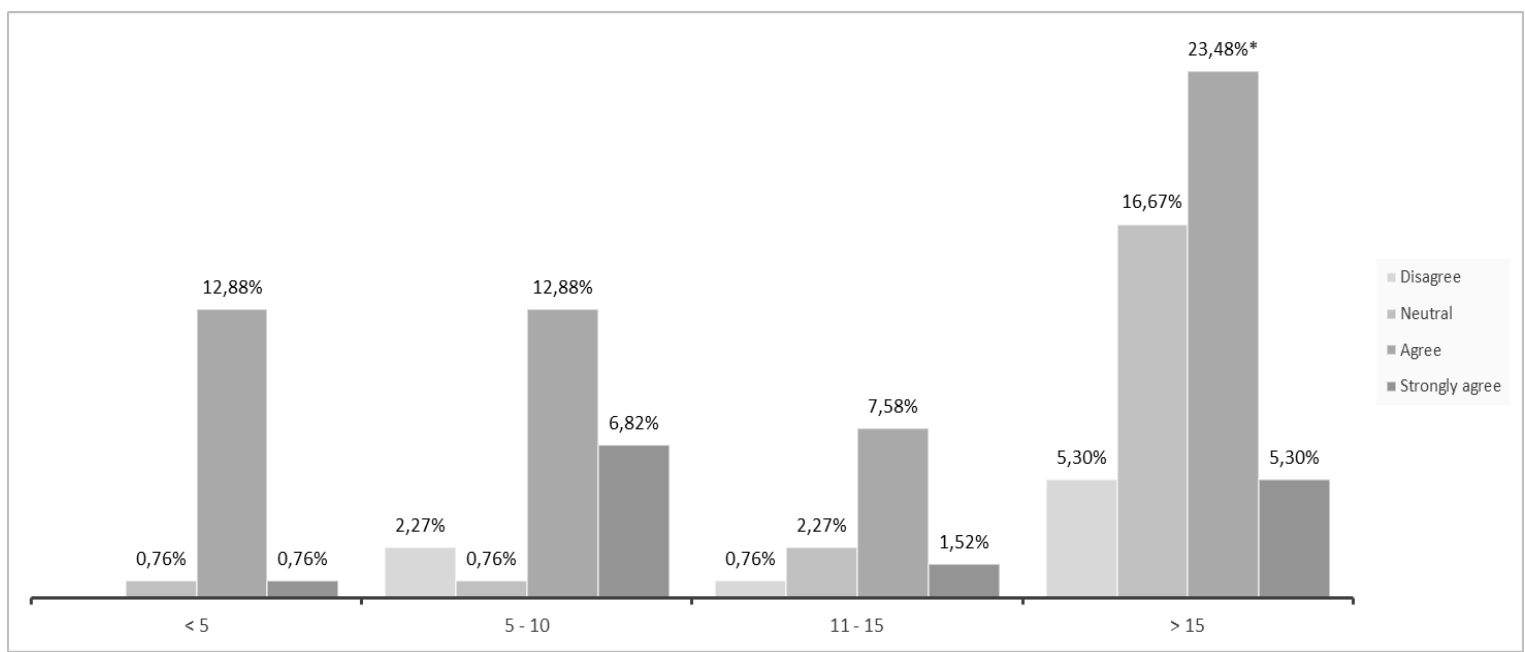

Graph 7 - Distribution of answers to the question: "EBP helps me to make decisions about the clinical management of patients" compared to "Years of habilitation", MARCHE.

Key: < 5: Less than 5 years, 5-10: Between 5 and 10 years, 11-15: Between 11 and 15 years, $>15$ : Greater than 15 years, *: Statistical significance $(\mathrm{p}<0.05)$.

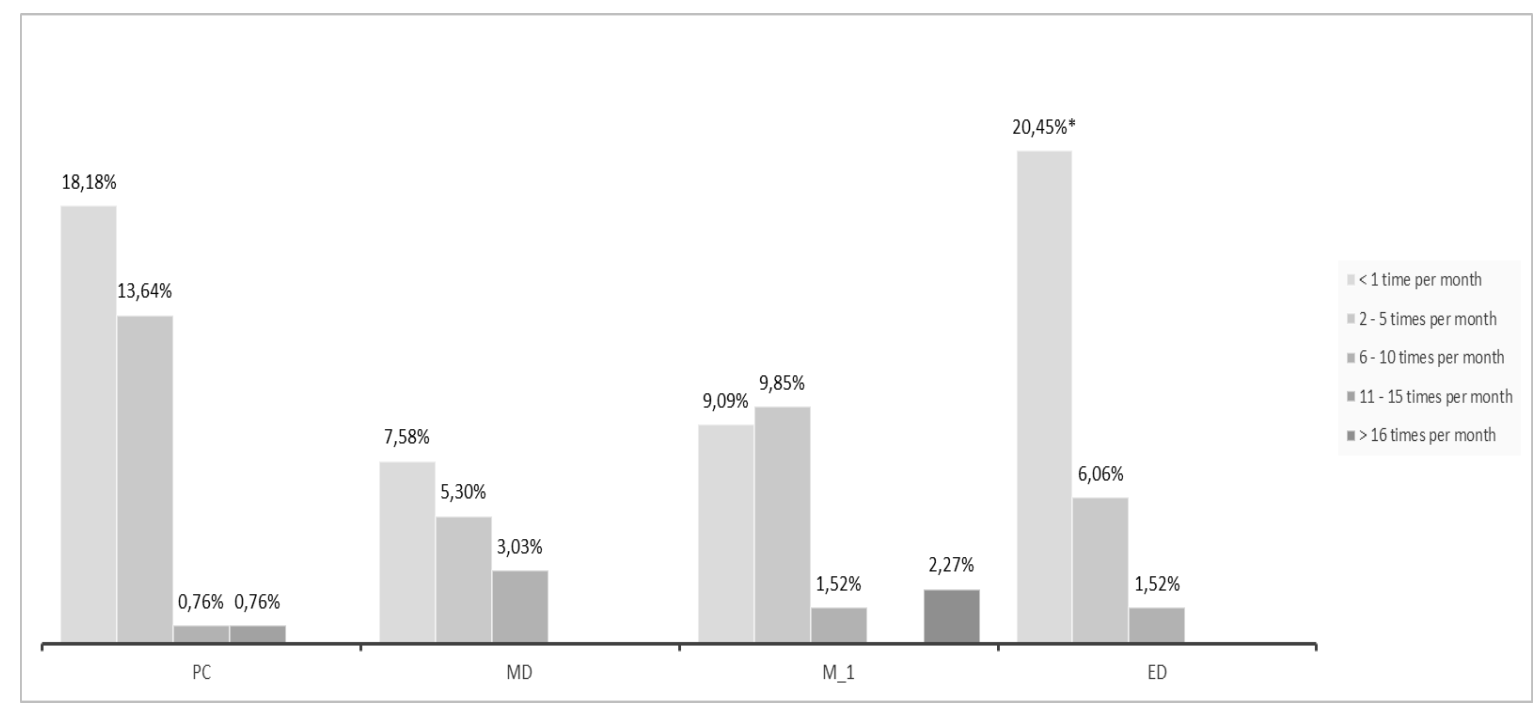

Graph 8 - Distribution of answers to the question: "I use PUBMED/MEDLINE or other databases to search for literature relevant to clinical practice" compared to "Equivalent Degree", MARCHE.

Key: PC: Postgraduate course, MD: Master's degree (LM/SNT2), M_1: Master's degree (1st level), M_2: Master's degree (2nd level), ED: Equivalent degree. 


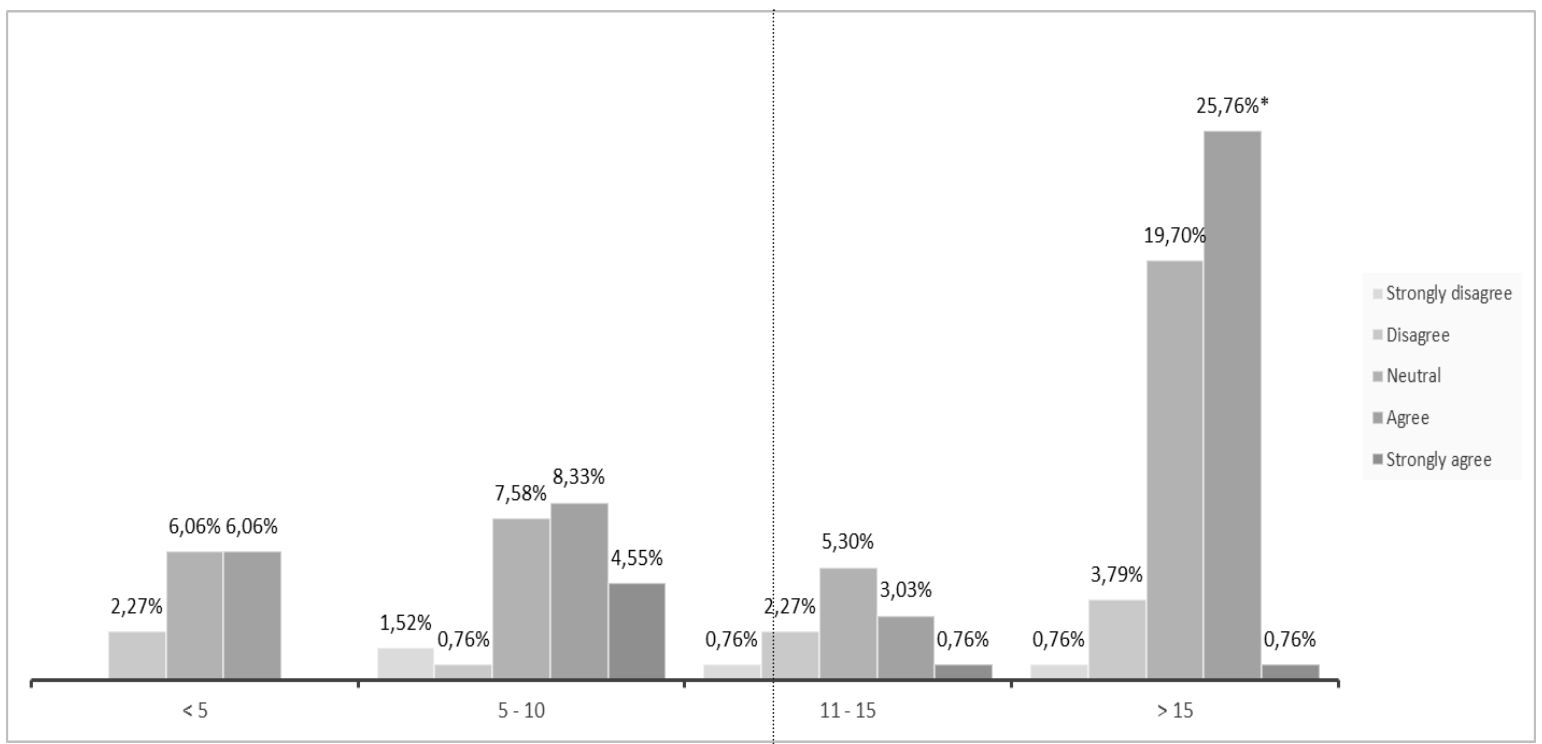

Graph 9 - Distribution of answers to the question: "Casereports are usually used to ascertain efficacy and risks of treatments, to identify new diseases, to recognize clinicalpresentations of rare diseases or unusual presentations of common diseases" compared to "years of habilitation", MARCHE.

Key: PC: Postgraduate course, MD: Master's degree (LM/SNT2), M_1: Master's degree (1st level), M_2: Master's degree (2nd level), ED: Equivalent degree.

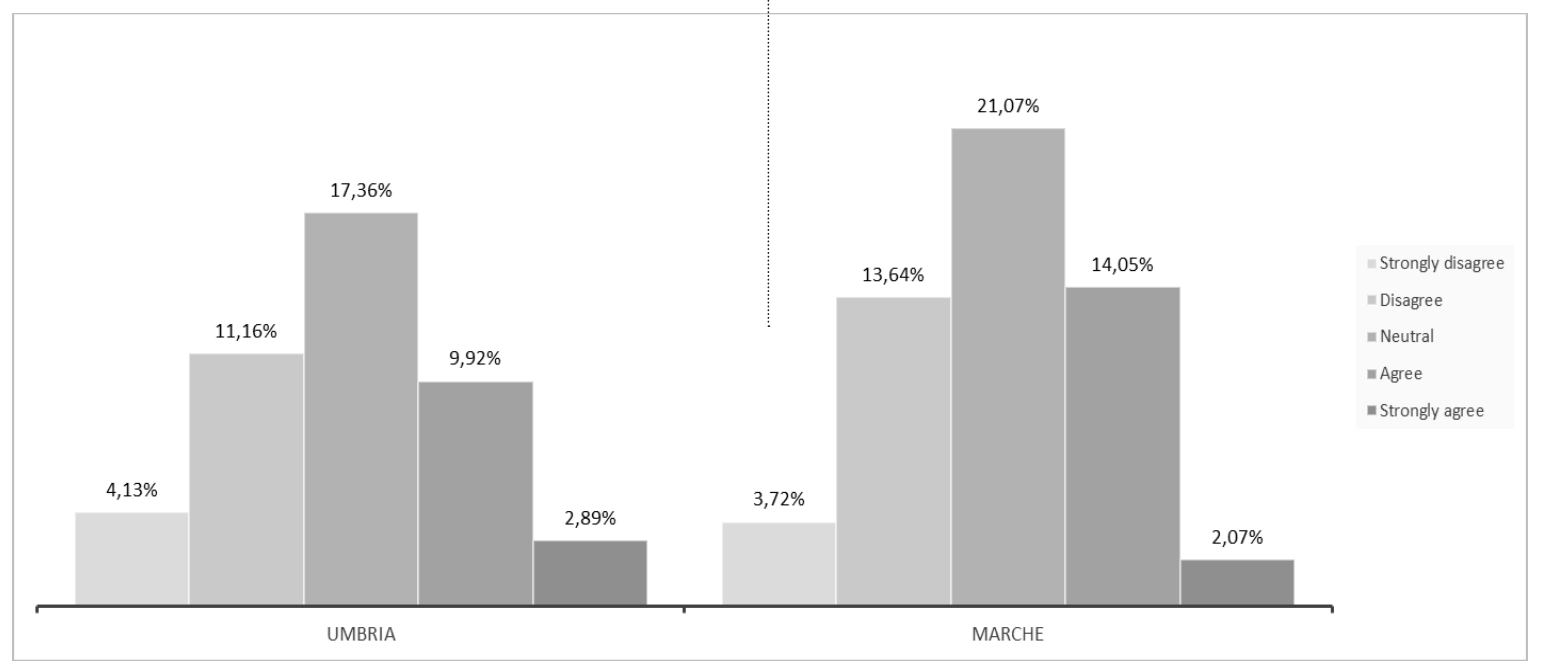

Graph 10 - Distribution of responses to the question: "EBP does NOT take patients' preferences into account" compared to the two REGIONS.

improving their skills in this area. They also stated that they would like to increase the amount of evidencebased evidence in their daily clinical practice. Many of the beliefs, skills and behaviors we examined are related to age, years since habilitation and graduation. Younger respondents, with more recent habilitation and qualifications in addition to a bachelor's degree or equivalent, tend to express more positive attitudes towards EBP and report having greater skills and confidence in accessing and in critical evaluation of information. The use of scientific search engines and the amount of reading that respondents reported doing in a typical month are correlated, above all, with respondents' age. In fact, those who have got the habilitation for less time are more likely to view more literature in a month. Furthermore, regarding the economic aspect, younger physiotherapists think that the more they know about EBP the more their economic income increases, while this is not relevant for physiotherapists over 50 years of age. Despite the limitations of this survey and the need for a larger sample size, the work allowed to note a set of information that shows an interesting overview of the importance of EBP in daily clinical practice for physiotherapists. From these data it is possible to draw indications of immediate use in order to define and improve future investigations related to this topic. It is hoped that future investigations can use this work as a starting point to evaluate the importance of EBP in clinical practice, establishing and delineating as precisely as possible the tools to be implemented to increase competencies in research and professional development in reference to EBP, this could only increase the quality and safety of care for the user.

\section{Acknowledgements}

The authors would like to thank the Register Commissions of Physiotherapists of the Umbria and Marche Regions, belonging to the TSRMPSRTP Order, for their assistance in distributing the questionnaire to colleagues in their respective areas of expertise. Further thanks are due to Ilaria Visciano for the translation of this paper. 


\section{Annex 1}

Questionnaire: Assessment of the importance of EBM/ EBP in daily clinical practice for physiotherapists. Survey in Marche and Umbria regions.

Presentation and introduction by the competent Roll Commission to all Physiotherapists enrolled in the Order TSRM-PSTRP of Perugia and Terni Dear colleagues, on the proposal of colleagues Collebrusco Luca, Gambacorta Andrea and Visciano Gennaro we send an anonymous questionnaire which aims is to evaluate if Evidence Based Practice has an impact in the daily clinical practice of the physiotherapist. We thank you in advance for your collaboration and remind you that the estimated time to complete the questionnaire is about 2 minutes. The questionnaire is based on a study conducted in the United States (Heiwe Susanne et al, "Evidence-based practice: attitudes, knowledge and behaviour among allied health care professionals"; 2011.) which highlights a clear discrepancy between the amount of existing research proofs and the use of this evidence in clinical practice. The study cited shows that between the $10 \%$ and $40 \%$ of American adult patients do not receive EBM-based care. It also shows that $20 \%$ of treatment is unnecessary and that $8.6 \%$ of people treated in this way are harmed. There is little research in Italy concerning the evaluation of physiotherapists' knowledge and behaviour towards EBP in daily clinical practice. Considering that all physiotherapists have the duty to work in compliance with article $n .22$ of the Deontological Code ("Update and continuous training"), with this survey we want to carry out an anonymous research on the level of knowledge and use of research methodology in clinical practice by physiotherapists in Marche and Umbria regions. The aim is to investigate the attitude and competences of the colleagues, in a way that, in case criticalities are highlighted, we can lay the foundations to build an information network that brings to an implementation of the knowledge and use of EBM/EBP.

\section{QUESTIONNAIRE}

\section{ANAGRAPHY}

Sex

- Male

- Female

Age

- 20-29

- 30-39

- 40-49

- $50+$

Do you have any qualifications other than the qualification?

- Postgraduate course

- Master's degree

- First level master's degree

- Second level master's Degree

- $\mathrm{PhD}$

- None
How many years have you been habilitated?

- $<5$

- $5-10$

- $11-15$

- $>15$

What is your specialisation?

- Neonatal and Paediatric Rehabilitation;

- Neurological/Neuropsychiatric Rehabilitation;

- Musculoskeletal Rehabilitation;

- Cardio-Respiratory Rehabilitation;

- Geriatric Rehabilitation;

- Sports Rehabilitation;

- Oncological rehabilitation;

- Visceral rehabilitation (phlebo lymphatic, perineal pelvis);

- More

Type of work

- Employee

- Freelancer

- Third-year student

Where in Umbria do you practice your profession?

- Perugia

- Terni

2. PERSONAL APTITUDES TOWARDS USE, PERCEIVED BENEFITS AND LIMITATIONS OF EVIDENCE-BASED PRACTICE

The application of EBP is necessary in the practice of physiotherapists.

- Strongly disagree

- Disagree

- Neutral

- Agree

- Strongly agree

Scientific literature and research results are useful in my daily practice

- Strongly disagree

- Disagree

- Neutral

- Agree

- Strongly agree

I need to increase the use of the evidence literature in my daily clinical practice.

- Strongly disagree

- Disagree

- Neutral

- Agree

- Strongly agree

Adaptation of practice based on evidence from the literature is an unreasonable demand for physiotherapists.

- Strongly disagree

- Disagree

- Neutral

- Agree

- Strongly agree 
I am interested in learning or improving the skills needed to incorporate evidence-based practice.

- Strongly disagree

- Disagree

- Neutral

- Agree

- Strongly agree

Evidence-based practice improves quality of care

- Strongly disagree

- Disagree

- Neutral

- Agree

- Strongly agree

Evidence-based practice does NOT take into account the limitations of my rehabilitation setting.

- Strongly disagree

- Disagree

- Neutral

- Agree

- Strongly agree

My gains increase if I use EBP in my daily practice.

- Strongly disagree

- Disagree

- Neutral

- Agree

- Strongly agree

Lack of clear evidence to support most of the interventions I use with my patients

- Strongly disagree

- Disagree

- Neutral

- Agree

- Strongly agree

EBP helps me to make decisions about the clinical management of patients

- Strongly disagree

- Disagree

- Neutral

- Agree

- Strongly agree

EBP does NOT take patient preferences into account

- Strongly disagree

- Disagree

- Neutral

- Agree

- Strongly agree

How many articles can you read if you combine research and clinical work in one month?

- 0 - 3 times a month

- 3 - 5 times a month
- 6 - 10 times per month

- 11 - 15 times per month

- $\geq 16$ times per month

Use of research results in the clinical/decisionmaking process.

- $<1$ time per month

- 2 - 5 times per month

- 6 - 10 times per month

- $11-15$ times per month

- $\geq 16$ times per month

I use PUBMED/MEDLINE or other databases to search for literature relevant to clinical practice.

- $<1$ time per month

- 2 - 5 times per month

- 6 - 10 times per month

- $11-15$ times per month

- $\geq 16$ times per month

\section{COMPETENCES RELATED TO EBP}

REVIEW and METANALYSIS are the studies with the highest quality of evidence.

- Strongly disagree

- Disagree

- Neutral

- Agree

- Strongly agree

Observational studies have a high quality of evidence.

- Strongly disagree

- Disagree

- Neutral

- Agree

- Strongly agree

Experimental studies have the highest quality of evidence.

- Strongly disagree

- Disagree

- Neutral

- Agree

- Strongly agree

Case reports are usually used to check efficacy and risks of treatments, identify new diseases, recognize clinical presentations of rare diseases or unusual presentations of common diseases.

- Strongly disagree

- Disagree

- Neutral

- Agree

- Strongly agree 


\section{REFERENCES}

1. Tugwell, P. Philadelphia panel evidence-based clinical practice guidelines on selected rehabilitation interventions for neck pain. Phys. Ther. 81, 1701-1717 (2001).

2. Scalzitti, D. A. Evidence-based guidelines: Application to clinical practice. Phys. Ther. 81, 1622-1628 (2001).

3. Jette, D. U. et al. Evidence-based practice: Beliefs, attitudes, knowledge, and behaviors of physical therapists. Phys. Ther. 83, 786-805 (2003).

4. Scurlock-Evans, L., Upton, P. \& Upton, D. Evidence-Based Practice in physiotherapy: A systematic review of barriers, enablers and interventions. Physiother. (United Kingdom) 100, 208-219 (2014).

5. Rose, S. J. Physical therapy diagnosis: Role and function. Phys. Ther. 69, 535-537 (1989).

6. Sackett, D. L. et al. Editorials Evidence based medicine: what it is and what it isn't. Bmj 312, 71-72 (1996).

7. Lim, J. H. \& Cho, D. W. Specular reflection probability in the certainty grid representation. J. Dyn. Syst. Meas. Control. Trans. ASME 116, 512-520 (1994).

8. El-sobkey, S. B. \& Helmy, A. M. Evidence-based practice and standardized outcome measures: Egyptian physical therapists' beliefs, perceptions and adoption. World Appl. Sci. J. 16, 1282-1291 (2012).

9. Guyatt, G. H. et al. Users' guides to the medical literature: XXV. Evidence-based medicine: Principles for applying the users' guides to patient care. J. Am. Med. Assoc. 284, 1290-1296 (20

10. Haynes, B. \& Haines, A. Getting research findings into practice. Barriers and bridges to evidence based clinical practice. Br. Med. J. 317, 273-276 (1998).

11. McColl, A., Smith, H., White, P. \& Field, J. General practitioners' perceptions of the route to evidence based medicine: A questionnaire survey. Br. Med. J. 316, 361-365 (1998).

12. Kajermo, K. N., Nordström, G., Krusebrant, A. \& Björvell, H. Barriers to and facilitators of research utilization, as perceived by a group of registered nurses in Sweden. J. Adv. Nurs. 27, 798-807 (1998).

13. Turner, P. \& Whitfield, T. W. Physiotherapists' use of evidence based practice: a cross-national study. Physiother. Res. Int. 2, 17-29 (1997).

14. Turner, P. \& Whitfield, A. Journal readership amongst Australian physiotherapists: A cross national replication. Aust. J. Physiother. 43, 197-202 (1997).

15. Castellini, G., Corbetta, D., Cecchetto, S. \& Gianola, S. Twenty-five years after the introduction of Evidence-based Medicine: knowledge, use, attitudes and barriers among physiotherapists in Italy - a cross-sectional study. BMJ Open 10, e037133 (2020).

16. Iles, R. \& Davidson, M. Physiotherapy diagnosis in clinical practice: a survey of orthopaedic certified specialists in the USA. Physiother. Res. Int. 11, 93-103 (2008).

17. Nilsagrd, Y. \& Lohse, G. Evidence-based physiotherapy: A survey of knowledge, behaviour, attitudes and prerequisites. Adv. Physiother. 12, 179-186 (2010). 